Prepared in cooperation with the U.S. Army Corps of Engineers

\title{
Effects of Proposed Navigation Channel Improvements on Sediment Transport in Mobile Harbor, Alabama
}

Open-File Report 2018-1123 



\section{Effects of Proposed Navigation Channel Improvements on Sediment Transport in Mobile Harbor, Alabama}

By Davina L. Passeri, Joseph W. Long, Robert L. Jenkins, and David M. Thompson

Prepared in cooperation with the U.S. Army Corps of Engineers

Open-File Report 2018-1123 


\title{
U.S. Department of the Interior \\ RYAN K. ZINKE, Secretary
}

\author{
U.S. Geological Survey \\ James F. Reilly II, Director
}

U.S. Geological Survey, Reston, Virginia: 2018

For more information on the USGS-the Federal source for science about the Earth, its natural and living resources, natural hazards, and the environment-visit https://www.usgs.gov/ or call 1-888-ASK-USGS (1-888-275-8747).

For an overview of USGS information products, including maps, imagery, and publications, visit https://store.usgs.gov.

Any use of trade, firm, or product names is for descriptive purposes only and does not imply endorsement by the U.S. Government.

Although this information product, for the most part, is in the public domain, it also may contain copyrighted materials as noted in the text. Permission to reproduce copyrighted items must be secured from the copyright owner.

Suggested citation:

Passeri, D.L., Long, J.W., Jenkins, R.L., and Thompson, D.M., 2018, Effects of proposed navigation channel improvements on sediment transport in Mobile Harbor, Alabama: U.S. Geological Survey

Open-File Report 2018-1123, 22 p., https://doi.org/10.3133/ofr20181123. 


\section{Acknowledgments}

This research was chartered by the U.S. Army Corps of Engineers Mobile District. The authors thank Soupy Dalyander and Elizabeth Godsey for reviewing this publication. Betsy Boynton and Rebekah Davis supported the review, editing, and publishing process. 



\section{Contents}

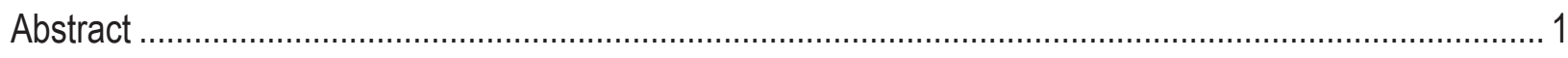

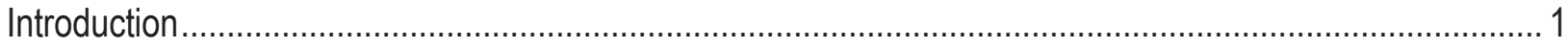

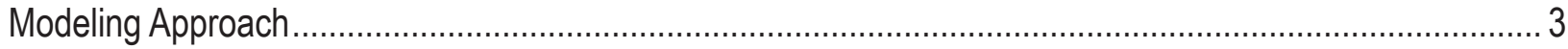

Proposed Navigation Channel Modifications ……………………................................................ 3

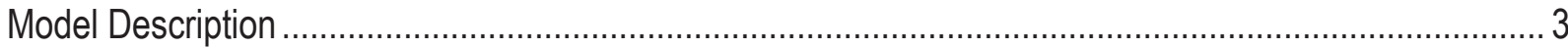

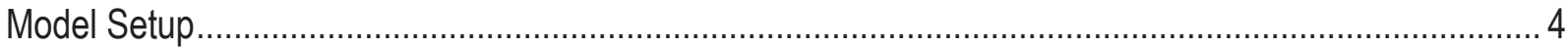

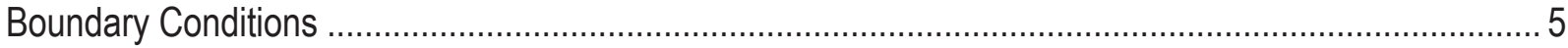

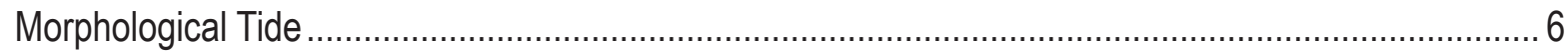

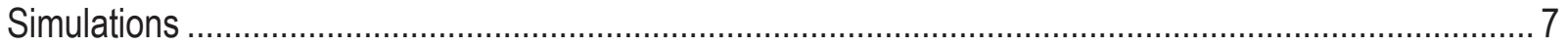

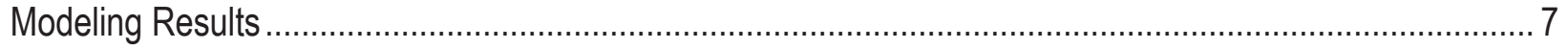

Model Performance ……………..............................................................................................

Modeled Versus Observed Bed Level Changes ……………................................................... 8

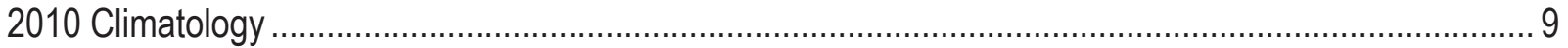

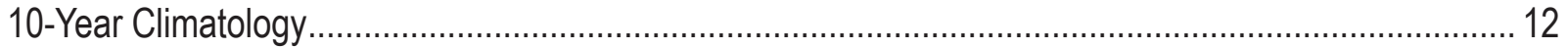

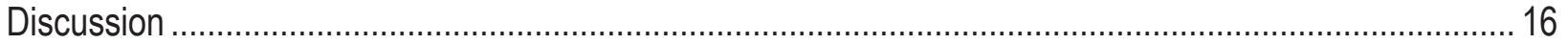

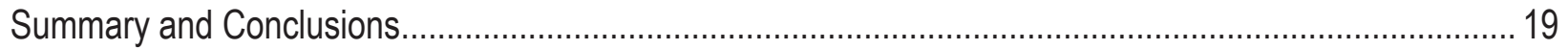

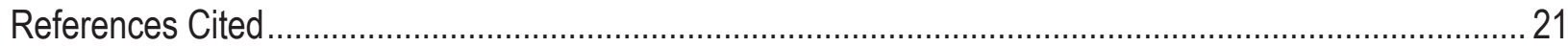

\section{Figures}

1. The Mobile Harbor study area, Alabama, including Mobile Bay and the navigational channel, which consists of the upper bay channel, the lower bay channel, and the entrance channel ............2

2. Delft3D model domains and initial elevations, Mobile Harbor, Alabama. ......................................

3. Observed bed level changes in Mobile Harbor, Alabama. A, from 2002 to 2014. B, from 2002 to 2015. C, from 2009 to 2014 .

4. Modeled bed level change in Mobile Harbor, Alabama. $A$, after 10 years in the 10-year existing condition simulation. $B$, after 5 years in the 10 -year existing condition simulation.

5. Changes in bed level for the 2010 simulations, Mobile Harbor, Alabama. A, existing conditions. $B$, with-project conditions. $C$, difference in final bed level between existing and with-project conditions ......

6. Changes in bed level for the 2010 simulations, Mobile Harbor, Alabama. A, existing conditions accounting for 0.5 meter of sea level rise. $B$, with-project conditions accounting for 0.5 meter of sea level rise. $C$, difference in final bed level between existing conditions accounting for 0.5 meter of sea level rise and with-project conditions accounting for 0.5 meter of sea level rise...12

7. Percent change in the volume of sediment eroded or deposited in the entrance channel, Mobile Harbor, Alabama. A, between 2010 existing and 2010 with-project conditions. B, between 2010 existing with 0.50 meter of sea level rise and 2010 with-project with 0.50 meter of sea level rise. 
8. Changes in bed level for the 10-year simulations, Mobile Harbor, Alabama. A, existing conditions. $B$, with-project conditions. $C$, difference in final bed level between existing and with-project conditions

9. Changes in bed level for the 10-year simulations, Mobile Harbor, Alabama. A, existing conditions accounting for 0.5 meter of sea level rise. $B$, with-project conditions accounting for 0.5 meter of sea level rise. $C$, difference in final bed level between existing conditions accounting for 0.5 meter of sea level rise and with-project conditions accounting for 0.5 meter of sea level rise ... 16

10. Percent change in the volume of sediment eroded or deposited in the entrance channel, Mobile Harbor, Alabama. A, between the 10-year existing and 10-year with-project conditions. $B$, between the 10-year existing condition with 0.50 meter of sea level rise and 10-year with-project condition with 0.50 meter of sea level rise.

\section{Tables}

1. Characteristics and percent occurrence of wave conditions for each wave bin for 10-year climatology and 2010 climatology, Mobile Harbor, Alabama.

2. Coefficients of determination and root mean square error values for through-channel and crosschannel velocity components during flood and ebb tide at inlet, volume flux during flood and ebb tide at inlet and water levels at the Dauphin Island tide gage, Mobile Harbor, Alabama.

3. Volume of sediment eroded or deposited in the entrance channel at the end of the 2010 simulations, Mobile Harbor, Alabama

4. Volume of sediment eroded or deposited in the entrance channel for the 10-year climatology simulations, Mobile Harbor, Alabama

5. Shoaling volume in the entrance channel at the end of each year for the 10-year simulations, Mobile Harbor, Alabama 


\section{Conversion Factors}

International System of Units to U.S. customary units

\begin{tabular}{|c|c|c|}
\hline Multiply & By & To obtain \\
\hline \multicolumn{3}{|c|}{ Length } \\
\hline meter $(\mathrm{m})$ & 3.281 & foot $(\mathrm{ft})$ \\
\hline kilometer $(\mathrm{km})$ & 0.6214 & mile (mi) \\
\hline kilometer $(\mathrm{km})$ & 0.5400 & mile, nautical (nmi) \\
\hline meter $(\mathrm{m})$ & 1.094 & yard (yd) \\
\hline \multicolumn{3}{|c|}{ Volume } \\
\hline cubic meter $\left(\mathrm{m}^{3}\right)$ & 6.290 & barrel (petroleum, 1 barrel = 42 gal) \\
\hline cubic meter $\left(\mathrm{m}^{3}\right)$ & 264.2 & gallon (gal) \\
\hline cubic meter $\left(\mathrm{m}^{3}\right)$ & 0.0002642 & million gallons (Mgal) \\
\hline cubic meter $\left(\mathrm{m}^{3}\right)$ & 35.31 & cubic foot $\left(\mathrm{ft}^{3}\right)$ \\
\hline cubic meter $\left(\mathrm{m}^{3}\right)$ & 1.308 & cubic yard $\left(\mathrm{yd}^{3}\right)$ \\
\hline cubic meter $\left(\mathrm{m}^{3}\right)$ & 0.0008107 & acre-foot (acre-ft) \\
\hline \multicolumn{3}{|c|}{ Flow rate } \\
\hline cubic meter per second $\left(\mathrm{m}^{3} / \mathrm{s}\right)$ & 70.07 & acre-foot per day (acre-ft/d) \\
\hline meter per second $(\mathrm{m} / \mathrm{s})$ & 3.281 & foot per second $(\mathrm{ft} / \mathrm{s})$ \\
\hline cubic meter per second $\left(\mathrm{m}^{3} / \mathrm{s}\right)$ & 35.31 & cubic foot per second $\left(\mathrm{ft}^{3} / \mathrm{s}\right)$ \\
\hline
\end{tabular}

\section{Datum}

Vertical coordinate information is referenced to the North American Vertical Datum of 1988 (NAVD 88).

Elevation, as used in this report, refers to the distance above the vertical datum.

\section{Abbreviations}

$\begin{array}{ll}\text { ADCP } & \text { acoustic Doppler current profiler } \\ \text { CoNED } & \text { Coastal National Elevation Database } \\ \text { DEM } & \text { digital elevation model } \\ \text { ECMWF } & \text { European Centre for Medium-Range Weather Forecast } \\ \text { HYCOM } & \text { Hybrid Coordinate Ocean Model } \\ \text { lidar } & \text { light detection and ranging } \\ \text { NGDC } & \text { National Geophysical Data Center } \\ \text { NOAA } & \text { National Oceanic and Atmospheric Administration } \\ R^{2} & \text { coefficient of determination } \\ \text { RMSE } & \text { root mean square error } \\ \text { SLR } & \text { sea level rise } \\ U & \text { through-channel velocity } \\ V & \text { cross-channel velocity }\end{array}$





\title{
Effects of Proposed Navigation Channel Improvements on Sediment Transport in Mobile Harbor, Alabama
}

\author{
By Davina L. Passeri, Joseph W. Long, Robert L. Jenkins and David M. Thompson
}

\begin{abstract}
A Delft3D model was developed to evaluate the potential effects of proposed navigation channel deepening and widening in Mobile Harbor, Alabama. The model performance was assessed through comparisons of modeled and observed data of water levels, velocities, and bed level changes; the model captured hydrodynamic and sediment transport patterns in the study area with skill. The validated model was used to simulate changes in sediment transport for existing conditions and with the proposed modifications to the navigational channel (with-project), with and without accounting for 0.5 meter $(\mathrm{m})$ of sea level rise (SLR). Each scenario was simulated for 1 year with a wave climatology representative of the year 2010 as well as for 10 years with a longer-term wave climatology spanning from 1988 to 2016. Bed level differences for the existing and with-project 2010 simulations were minimal, ranging from -0.11 to $0.11 \mathrm{~m}$ offshore of Pelican Island and -0.81 to $0.22 \mathrm{~m}$ offshore of the Fort Morgan Peninsula. For the simulations accounting for $0.5 \mathrm{~m}$ of SLR, differences in bed levels from -0.20 to $0.32 \mathrm{~m}$ near Pelican Island and -0.38 to $0.34 \mathrm{~m}$ offshore of the Fort Morgan Peninsula. The proposed modifications reduced the channel shoaling volume by 4.77 and 8.09 percent for the 2010 simulations without and with $0.5 \mathrm{~m}$ of SLR, respectively. For the 10 -year simulations, bed level differences for the existing and with-project simulations ranged from -3.17 to $3.94 \mathrm{~m}$ for the simulation without SLR and -1.92 to $1.47 \mathrm{~m}$ for the simulation with $0.5 \mathrm{~m}$ of SLR. The with-project condition reduced the entrance channel shoaling volume by 5.54 percent for the simulation without SLR and 14.98 percent for the simulation with $0.5 \mathrm{~m}$ of SLR.
\end{abstract}

\section{Introduction}

Mobile Harbor is in southwest Alabama in the northern Gulf of Mexico (fig. 1). The U.S. Army Corps of Engineers (USACE) proposed to deepen and widen the existing navigation channel in Mobile Harbor as part of an economic analysis to determine the feasibility of channel improvements. To evaluate the potential effects of channel deepening and widening on the morphology of the ebb tidal shoal and adjacent areas, the USACE Mobile District requested the support of the U.S. Geological Survey in numerical modeling of waves, currents, and sediment transport for the Mobile Harbor General Reevaluation Report. A numerical modeling approach was implemented to quantify relative changes in sediment pathways and the morphological response on the ebb tidal shoal because of the increased channel dimensions. A Delft3D model was developed to simulate changes in sediment transport under existing conditions and accounting for $0.5 \mathrm{~m}$ of sea level rise, with and without modifications to the navigation channel. Each scenario was simulated for a 1- and 10-year period; the 1-year simulation used a climatology 
representative of the year 2010, and the 10-year simulation used a long-term wave climatology for the region. Model output was used to infer potential effects to sediment delivery at the inlet ebb tidal shoal and towards Dauphin Island, Alabama.

\section{Modeling Approach}

A Delft3D model was developed and used to quantify relative changes in sediment transport and the morphologic response on the ebb tidal shoal under existing conditions and with

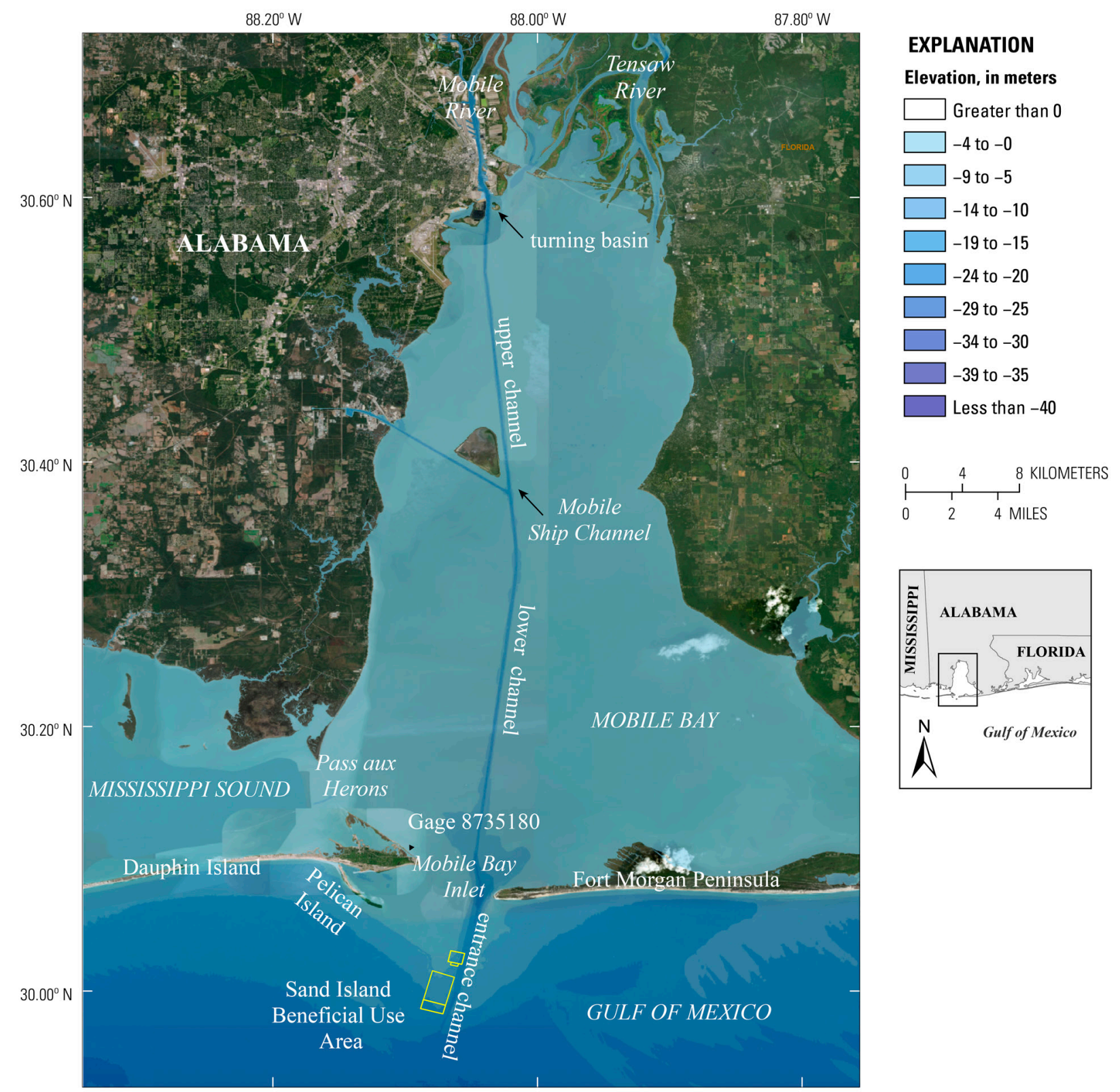

Service Layer Credits: Source: Esri,DigitalGlobe, GeoEye, EarthstarGeographics, CNES/Airbus DS, USDA, USGS, AEX, Getmapping, Aerogrid, IGN,IGP, swisstopo, and the GIS UserCommunity

Figure 1. The Mobile Harbor study area, Alabama, including Mobile Bay and the navigational channel, which consists of the upper bay channel, the lower bay channel, and the entrance channel. 
the proposed channel modification. Details on the development of the model grid, initial model elevations, and boundary conditions are provided herein. The model grid and initial elevations are provided in Passeri and others (2018).

\section{Proposed Navigation Channel Modifications}

Mobile Harbor includes Mobile Bay, which connects to the Gulf of Mexico through the Mobile Bay inlet bounded by the Fort Morgan Peninsula and Dauphin Island (fig. 1). North of Dauphin Island, Mobile Bay connects to the Mississippi Sound through Pass aux Herons (fig. 1.). The Mobile Harbor navigation channel spans the length of Mobile Bay and includes the entrance channel, which extends from the mouth of Mobile Bay southward into the Gulf of Mexico, and the lower and upper bay channels, which extend from the mouth of the bay northward (fig. 1). The existing depth at the entrance channel is 14.33 meters ( $\mathrm{m}$, North American Vertical Datum of 1988) with an additional $0.61 \mathrm{~m}$ for advanced maintenance (that is, additional dredging depth to avoid re-dredging) and $0.61 \mathrm{~m}$ for allowable overdepth dredging (total of $15.54 \mathrm{~m}$ ). The existing depth in the lower and upper channels is $13.72 \mathrm{~m}$ with an additional $0.61 \mathrm{~m}$ for advanced maintenance and $0.61 \mathrm{~m}$ for allowable overdepth dredging (total of $14.94 \mathrm{~m}$ ). The proposed project depths would deepen the entrance channel to $15.85 \mathrm{~m}$ with an additional $0.61 \mathrm{~m}$ for advanced maintenance and $0.61 \mathrm{~m}$ for allowable overdepth dredging (total of $17.07 \mathrm{~m}$ ), and the lower and upper channels to $15.24 \mathrm{~m}$ with an additional $0.61 \mathrm{~m}$ for advanced maintenance and $0.61 \mathrm{~m}$ for allowable overdepth dredging (total of $16.46 \mathrm{~m}$ ). The turning basin (fig. 1), at the northernmost part of the upper bay channel would be widened $76.2 \mathrm{~m}$ southward. The channel from the mouth of the bay northward for 8.04 kilometers would be widened from 121.92 to $152.4 \mathrm{~m}$ to include a passing lane.

\section{Model Description}

Delft3D (developed by Deltares; see Lesser and others, 2004) is an integrated process-based model consisting of multiple modules used to simulate wave propagation, wave and tidal currents, sediment transport, and morphologic change. The FLOW module (Deltares, 2018a) solves the nonlinear shallow water equations for incompressible free surface flows in two (depth-integrated) or three dimensions. The WAVE module (Deltares, 2018b) solves the spectral action density equation and computes wave radiation stresses and gradients that drive nearshore circulation. When coupled with the FLOW module, the WAVE module accounts for the effects of water level variations and wave-current interaction processes such as frequency shifting. The sediment transport module solves for suspended and bed load sediment transport. To calculate suspended load, the three-dimensional advection-diffusion equation is solved, accounting for sediment concentration, flow velocities, eddy diffusivity, and sediment settling velocity. For bed load transport of non-cohesive sediments, the transport equation is solved accounting for bed slope, bed composition, spatially variable bed friction coefficients, and concentration of available sediment. Breaking-induced shear stresses, mass flux, and bed shear stress are included in the transport of suspended sediments and fluxes from bed load sediments. The transport module evolves bed morphology on the basis of mass fluxes between suspended and bed load sediments. More detailed information on the Delft3D model is provided in Lesser and others (2004).

Delft3D was operated using the mormerge approach (Roelvink, 2006), which is a configuration of the model in which multiple simulations run simultaneously with identical initial 
bed conditions but with unique wave forcing. Each simulation is assigned a weight according to the percent occurrence of the wave conditions from a wave climatological assessment. At each half model time step, the current bathymetry from each of the simulation bins is combined using a weighted-average to form a new shared bathymetry that is passed back to each simulation and applied as the bathymetry for all the concurrent simulations for the next time step. The cumulative effect is a computationally efficient way to perform long-term morphological predictions.

\section{Model Setup}

For this study, three computational grids were used (see grid extents in fig. 2). The FLOW module uses a curvilinear grid consisting of 1,368 x 657 grid points. Cross-shore grid resolution ranges from less than $5 \mathrm{~m}$ over Dauphin Island and in the surf zone to greater than $300 \mathrm{~m}$ in the northernmost reaches of Mobile Bay. The alongshore grid resolution ranges from $40 \mathrm{~m}$ at Dauphin Island and across the Mobile Bay inlet to $100 \mathrm{~m}$ grid spacing at points in the southeastern quarter of the grid. The WAVE module uses two grids: a coarse outer grid and a nested fine grid. The coarse outer grid covers the study area with 245 x 449 grid points. It has variable alongshore resolution ranging from 250 to $325 \mathrm{~m}$ and variable cross-shore resolution ranging from 15 to $300 \mathrm{~m}$. The spatial extent of the nested fine grid is limited in latitude to the mouth of Mobile Bay where substantial wave-current interactions are expected and higher resolution is required. The fine grid consists of $1,367 \times 458$ grid points with a variable cross-shore resolution less than $5 \mathrm{~m}$

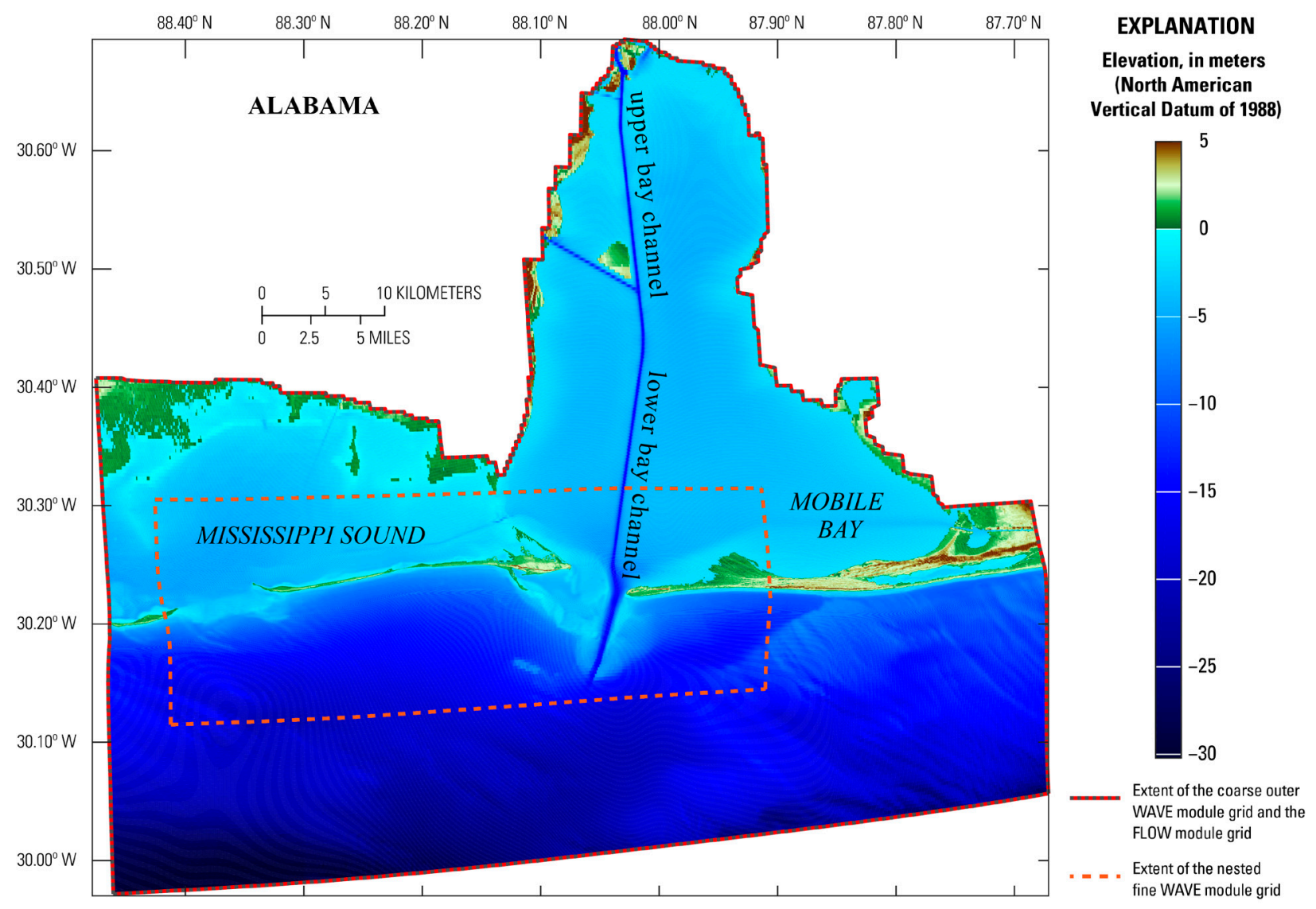

Figure 2. Delft3D model domains (computational grid extents) and initial elevations (existing condition), Mobile Harbor, Alabama. 
at the mouth of the bay to more than $250 \mathrm{~m}$ offshore and to the north. The alongshore resolution of the fine grid is $100 \mathrm{~m}$ along Dauphin Island and becomes coarser east of the Mobile Bay inlet.

Two digital elevation models (DEMs) were created for this study and used to initialize the model to represent (1) the existing bathymetry of Mobile Harbor and the navigation channel and (2) the proposed channel modifications. The base DEM was derived by combining the Coastal National Elevation Database (CoNED) topobathymetric DEM for Mobile Bay (Danielson and others, 2013) and the National Geophysical Data Center (NGDC) coastal DEM (National Geophysical Data Center and others, 2009). The NGDC coastal DEM covers the full extent of the modeling domain and was used primarily for offshore regions that were not included in the CoNED DEM, which contains more recent elevations in the coastal areas. A 2015 bathymetric survey at Dauphin Island (DeWitt and others, 2017) and a 2015 airborne light detection and ranging (lidar) survey of Dauphin Island (U.S. Geological Survey, 2016), also were merged into the DEM using the controlled interpolation methods of Plant and others (2002). For updated coverage, the USACE Mobile District provided elevations within Mobile Bay, including the navigation channel, based on a composite of recent bathymetric surveys (taken by the district) for the existing condition in addition to the altered bathymetry for the proposed with-project condition. These data were incorporated within Mobile Bay east of Pass aux Herons and within the entrance channel limited to the south by the 16-m contour. For depths greater than $5 \mathrm{~m}$, a region was defined using a contour of the minimum difference between the USACE depth and the underlying merged product of NGDC, CoNED, and the 2015 bathymetric and lidar surveys to ensure a continuous bathymetry. The USACE depth was then interpolated onto the FLOW grid and applied only to this defined region.

\section{Boundary Conditions}

\section{Wave Climatology}

The wave climatology was developed using output from the European Centre for Medium-Range Weather Forecast (ECMWF) ERA-Interim reanalysis model (Dee and others, 2011). For the 10-year simulations, significant wave height $(H s)$, peak wave period $(T p)$ and mean wave direction $(\mathrm{Dm})$ from January 1, 1998, to January 1, 2016, at a model grid point at longitude $-88.125 \mathrm{~W}$ and latitude $30.000 \mathrm{~N}$ were used to define the regional wave climatology. Periods with waves not directed towards shore between $110^{\circ}$ and $250^{\circ}$ (nautical convention) were assumed to minimally affect the study site and therefore were removed from the time series. To validate the model wave height, data from National Data Buoy Center buoy 42040 (National Data Buoy Center, 2018) and from an ECMWF model (Dee and others, 2011) grid point about 6 kilometers away from the buoy were compared for times of overlapping data. A linear regression analysis revealed that using a correction factor of 1.22 improved the modeled wave height; the coefficient of determination $\left(R^{2}\right)$ was 0.86 and the root mean square error (RMSE) was $0.26 \mathrm{~m}$. The Energy Flux Method of Benedet and others (2016) was then used to derive a binned (grouped) wave climatology where wave direction and height bin boundaries were defined such that all bins contained an equal amount of wave energy flux. The wave climate was divided into nine wave classes (three directions and three heights). For each defined bin, wave period is the mean period of the bin, wave direction is mean direction of the bin, and wave height is calculated from the mean wave energy flux in the bin assuming linear wave theory (table 1). For the 2010 simulations, the wave climate was derived similarly using ECMWF ERA-Interim data for 2010 (table 1). 
Table 1. Characteristics and percent occurrence of wave conditions for each wave bin for 10-year climatology and 2010 climatology, Mobile Harbor, Alabama.

\begin{tabular}{ccccc}
\hline Row & $\begin{array}{c}\text { Significant Wave } \\
\text { height (Hs), in meters }\end{array}$ & $\begin{array}{c}\text { Peak wave period }(T p), \\
\text { in seconds }\end{array}$ & $\begin{array}{c}\text { Mean wave direction } \\
(\mathbf{D m}), \text { in degrees }\end{array}$ & $\begin{array}{c}\text { Occurrence, in } \\
\text { percent }\end{array}$ \\
\hline \multicolumn{5}{c}{ 10-year climatology } \\
\hline Bin 1 & 0.59 & 6.24 & 129.2 & 26.2 \\
Bin 2 & 0.59 & 6.43 & 154.01 & 25.4 \\
Bin 3 & 0.58 & 5.75 & 199.77 & 28.9 \\
Bin 4 & 1.21 & 7.3 & 128.1 & 5.3 \\
Bin 5 & 1.18 & 7.49 & 154.48 & 5.4 \\
Bin 6 & 1.23 & 7.22 & 195.49 & 5.2 \\
Bin 7 & 2.65 & 9.09 & 126.94 & 0.9 \\
Bin 8 & 2.17 & 8.6 & 155.06 & 1.4 \\
Bin 9 & 2.26 & 8.68 & 198.13 & 1.3 \\
\hline & & 2010 climatology & & 24.55 \\
\hline Bin 1 & 0.61 & 6.36 & 130.13 & 23.43 \\
Bin 2 & 0.61 & 6.52 & 155.87 & 27.69 \\
Bin 3 & 0.61 & 5.55 & 201.33 & 7.85 \\
Bin 4 & 1.03 & 7.02 & 129.71 & 5.16 \\
Bin 5 & 1.17 & 7.75 & 157.27 & 3.92 \\
Bin 6 & 1.39 & 7.41 & 197.34 & 2.69 \\
Bin 7 & 1.63 & 8.02 & 133.33 & 2.8 \\
Bin 8 & 1.67 & 8.13 & 158.77 & 1.91 \\
Bin 9 & 2.01 & 8.37 & 201.29 & \\
\hline
\end{tabular}

\section{Morphological Tide}

In addition to the wave forcing, a tidal time series or "morphological tide" was applied at the model boundaries to capture current velocities and morphological change associated with the neap-spring tide cycle. The morphological tide was calculated following the method of Lesser (2009), which is applicable in locations where the lunar diurnal K1 and O1 tidal constituents substantially contribute to the tidal signal, as is the case in the study domain. Tidal constituent amplitudes and phases were obtained from the National Oceanic and Atmospheric Administration (NOAA) tide gage (8735180) at the eastern end of Dauphin Island (fig. 1) and used to generate the amplitude and phases of the morphological tide. These were applied at the boundaries of each Delft3D simulation. For model stability, a consistent and progressive phase shift also was added to the morphological tide constituents of each successive wave bin.

\section{Simulations}

To assess the model performance, two deterministic simulations were conducted to compare modeled current velocities and water levels with collected data. Acoustic Doppler current profiler (ADCP) measurements were collected at the Mobile Bay inlet from August 27 
through 29, 2015 (representing the flood tide), and December 19 through 11, 2015 (representing the ebb tide). For each deterministic simulation, the existing Mobile Harbor DEM was used as the initial depth input with boundary conditions of modeled wind, wave, and water levels from the NOAA Hybrid Coordinate Ocean Model (HYCOM) (Bleck 2002) and the NOAA Wavewatch3 model (Tolman 1989). In comparing the modeled HYCOM water levels to the observed water levels at the Dauphin Island tide gage (station 8735180), the HYCOM water levels on average were $0.21 \mathrm{~m}$ lower than the observed; therefore, an offset of $0.21 \mathrm{~m}$ was added to the HYCOM water levels. Each simulation was spun-up for 12 hours before the first observation. In addition, a 6-month deterministic simulation from June 19 through November 20, 2005, was done to compare modeled water levels with observations at the Dauphin Island tide gage (Center for Operational Oceanographic Products and Services, 2018).

For the 2010 and 10-year simulations, four scenarios were examined: existing conditions (that is, existing bathymetric conditions of the coastal nearshore areas with no channel modifications), with-project conditions (that is, with the proposed channel modifications), existing conditions with a moderate sea level rise (SLR) of $0.50 \mathrm{~m}$, and with-project conditions with a moderate SLR of $0.50 \mathrm{~m}$. For the 10-year simulations, the channel depths were reset to the initial depths at the start of each year, assuming annual dredging would take place. Additionally, a volume of 503,606.21 cubic meters $\left(\mathrm{m}^{3}\right)$ of sand was added to the DEM in the southern section of the Sand Island Beneficial Use Area, on the 10-m contour southeast of Pelican Island (fig. 1), at the end of each year to account for the average annual volume of maintenance dredge material placement during 1999-2015.

\section{Modeling Results}

The results of the Delft3D simulations are presented herein. To evaluate the model performance, output in the form of water levels, velocities, and bed level from the deterministic simulations were compared with observations. To assess the effects of the proposed channel modifications, the final bed levels were extracted as output from the model at the end of the 2010 and 10 -year simulations, with and without $0.50 \mathrm{~m}$ of sea level rise (SLR). Model output from each simulation is provided in Passeri and others (2018).

\section{Model Performance}

\section{Modeled Versus Observed Water Levels and Velocities}

Modeled water velocities were interpolated to the ADCP transect at the Mobile Bay inlet. Modeled and observed water levels were rotated from their respective native coordinates to stream-wise coordinates so that the resulting velocity constituents were a stream-wise $U$ (through-channel) velocity and a $V$ (cross-channel) velocity. The $R^{2}$ and RMSE values between the modeled and observed $U$ and $V$ velocities in the Mobile Bay inlet are summarized in table 2. The $R^{2}$ values for the modeled and observed $U$ velocities during ebb and flood tide are 0.93 and 0.66 , respectively. The $R^{2}$ values for the modeled and observed $V$ velocities during ebb and flood tide were 0.79 and 0.30 , respectively. An additional comparison of modeled and observed volumetric fluxes calculated across the transect was done for the two ADCP observational periods (table 2). Fluxes were defined as stream-wise, depth-averaged velocities multiplied by water depth and integrated over the observation transect. A linear fit and $R^{2}$ value was calculated for the ebb and flood tide fluxes, resulting in values of 0.98 and 0.79 , respectively. The high skill during 
ebb tides shows the model's ability to accurately capture the ebb-dominant behavior of the inlet, which affects sediment transport out of the bay.

The observed water levels at the Dauphin Island tide gage were compared with modeled water levels extracted from the closest grid point to the tide gage location (table 2). The $R^{2}$ value between the observed and modeled water levels was 0.68 . Model error is likely due in part to the absence of lower frequency harmonic constituents in the boundary forcing.

\section{Modeled Versus Observed Bed Level Changes}

Modeled and observed changes in bed levels were compared to evaluate the model's capability to accurately simulate sediment transport. The USACE Mobile District provided changes in bed levels at various locations in the study area from the periods of 2009-14, 2002-14, and 2002-15 (the range of uncertainty is plus or minus $[ \pm] 0.61 \mathrm{~m}$ ). The changes in bed level were calculated from bathymetric surveys by Byrnes and others (2012), Flocks and others (2017), and the NGDC (National Ocean Service, 2014). Changes in bed levels from 2002 to 2014 and 2002 to 2015 indicate erosion and deposition along the 5-m contour extending from Pelican Island, and deposition along the eastern edge of the navigation channel offshore of the Fort Morgan Peninsula (figs. 3A, 3B). These changes were compared with the modeled change in bed level at the end of the 10-year existing simulation (that is, the year 10 final bed level minus the year 1 initial bed level). The simulation shows similar patterns of erosion and deposition along the 5-m contour and along the navigation channel (fig. $4 A$ ). It is important to note that the simulation was not initialized with 2002 bathymetry, so the magnitude of differences is not expected to match exactly. Additionally, the magnitude of the sediment placed in the Sand Island beneficial use area is not expected to match exactly because an annual average was applied in the simulation.

Observed bed level changes on the ebb tidal shoal between 2009 and 2014 indicate plus or minus $( \pm) 1 \mathrm{~m}$ erosion and deposition in between the 5 - and 10 -m contours (fig. $3 \mathrm{C}$ ). For comparison, bed levels were extracted after year 5 in the 10 -year simulation and used to calculate the change in bed level. Similar to the observation, there are patterns of erosion and deposition between the 5- and 10-m contours, as well as the dredge placement in the Sand Island Beneficial Use Area (fig. 4B). The magnitude of the difference is less than the observed data, but again, this

Table 2. Coefficients of determination and root mean square error values for through-channel and crosschannel velocity components during flood and ebb tide at inlet, volume flux during flood and ebb tide at inlet and water levels at the Dauphin Island tide gage, Mobile Harbor, Alabama.

$\left[R^{2}\right.$, coefficient of determination; RMSE, root mean square error; $U$, through channel; $\mathrm{m} / \mathrm{s}$, meter per second; $V$, cross channel; $\mathrm{m}^{3} / \mathrm{s}$, cubic meter per second; $\mathrm{m}$, meter]

\begin{tabular}{ccc}
\hline Constituent & $R^{2}$ & RMSE \\
\hline Ebb $U$ velocity & 0.93 & $0.11 \mathrm{~m} / \mathrm{s}$ \\
Ebb $V$ velocity & 0.79 & $0.06 \mathrm{~m} / \mathrm{s}$ \\
Flood $U$ velocity & 0.66 & $0.12 \mathrm{~m} / \mathrm{s}$ \\
Flood $V$ velocity & 0.30 & $0.07 \mathrm{~m} / \mathrm{s}$ \\
Ebb tide flux & 0.98 & $1.53 \times 10^{6} \mathrm{~m}^{3} / \mathrm{s}$ \\
Flood tide flux & 0.79 & $1.85 \times 10^{6} \mathrm{~m}^{3} / \mathrm{s}$ \\
Water level & 0.68 & $0.09 \mathrm{~m}$ \\
\hline
\end{tabular}



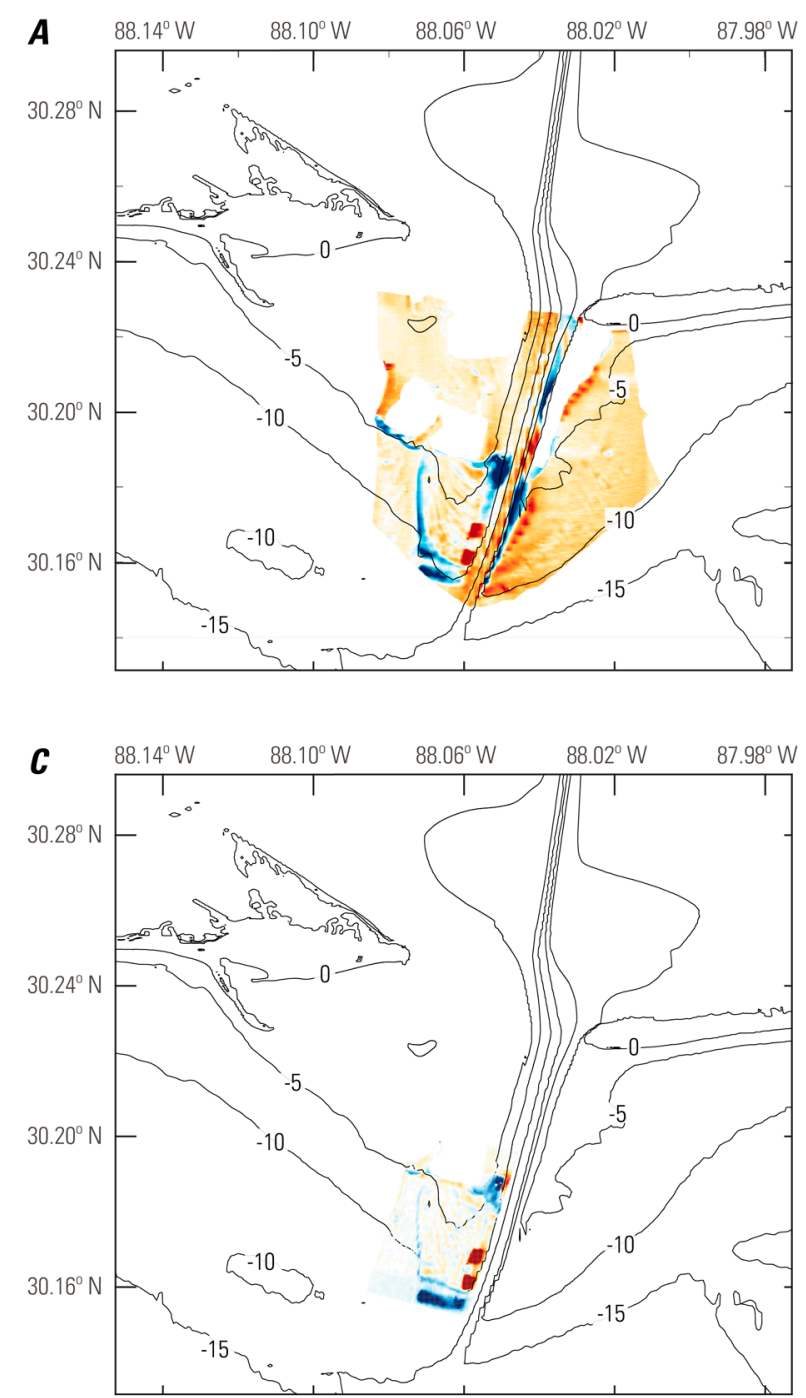

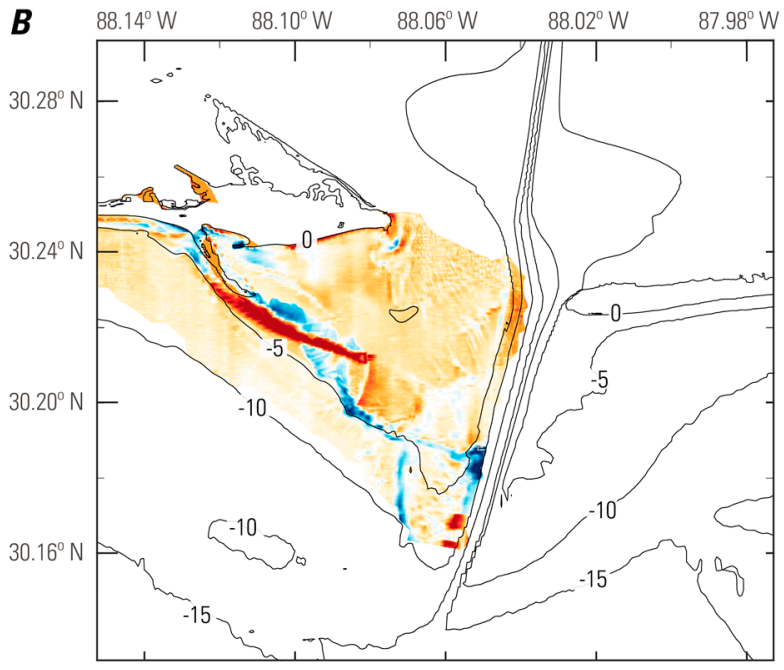

EXPLANATION

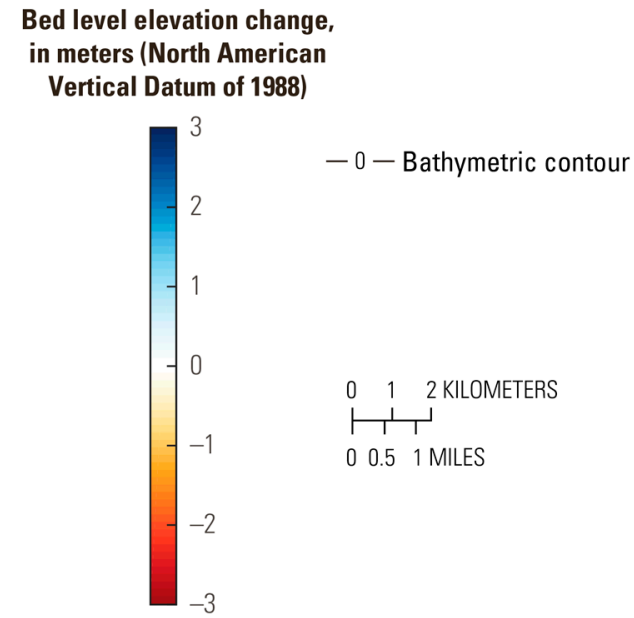

Figure 3. Observed bed level changes in Mobile Harbor, Alabama. A, from 2002 to 2014. B, from 2002 to 2015. C, from 2009 to 2014. Differences greater than 0 indicate deposition, and differences less than 0 indicate erosion.

simulation was not initialized with 2009 bathymetry and does not include tropical storms that would have occurred during this period.

\section{Climatology}

The change in bed level at the end of the 2010 simulation for the existing and with-project conditions is illustrated in figures 5A and 5B. Both simulations indicate erosion and deposition along the 5-m contour extending out from Pelican Island, as well as offshore of the Fort Morgan Peninsula. The difference in the final bed levels between the existing and with-project conditions is shown in figure $5 C$. Results indicate that there are minor changes in bed levels near Pelican Island (ranging from -0.11 to $0.11 \mathrm{~m}$ ) and offshore of the Fort Morgan Peninsula (ranging from -0.81 to $0.22 \mathrm{~m}$ ) with the proposed channel modification; these changes were confined within the 5-m contour. Similarly, figures $6 \mathrm{~A}$ and $6 \mathrm{~B}$ illustrate the change in bed level at the 

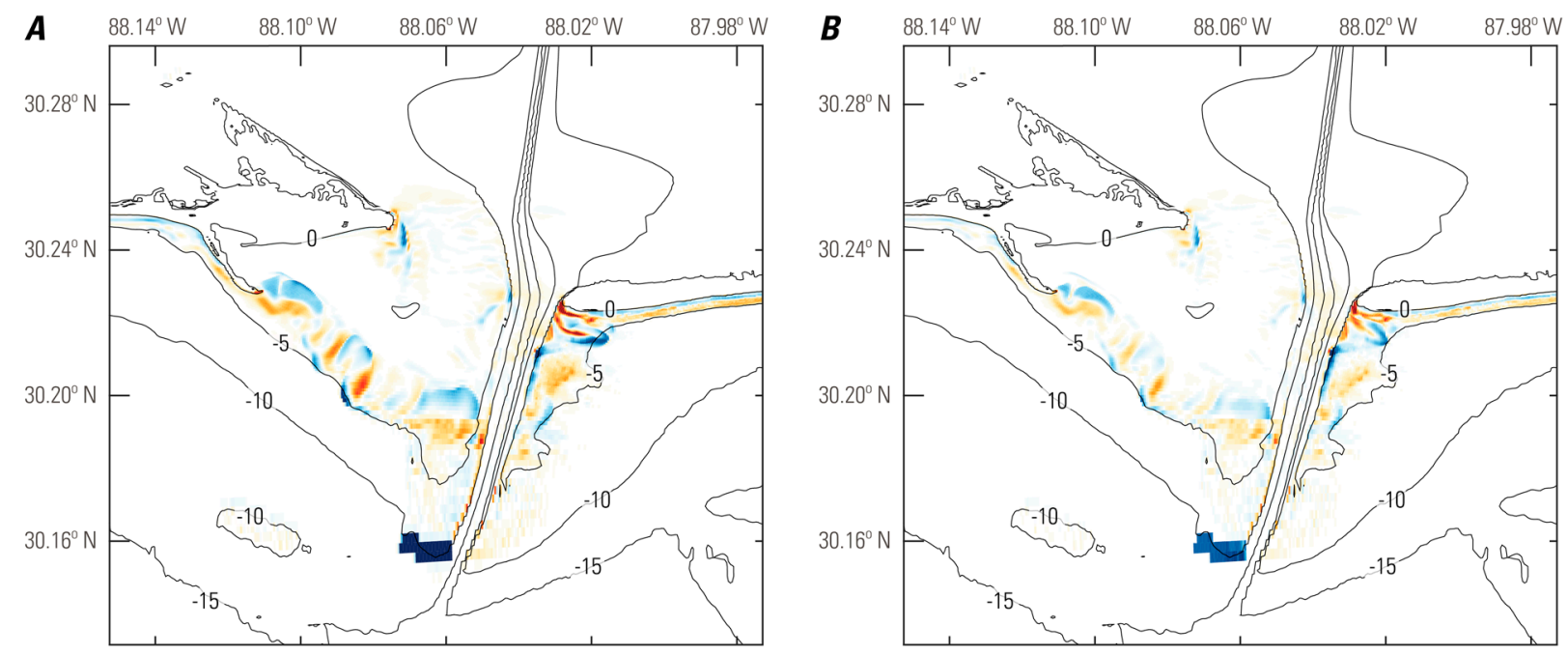

EXPLANATION

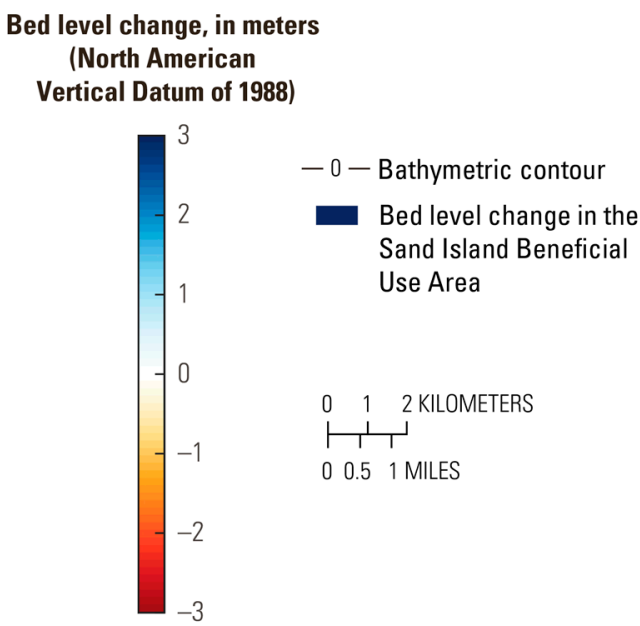

Figure 4. Modeled bed level change in Mobile Harbor, Alabama. $A$, after 10 years in the 10-year existing condition simulation. $B$, after 5 years in the 10-year existing condition simulation. Differences greater than 0 indication deposition, and differences less than 0 indicate erosion.

end of the 2010 simulation for the existing condition with $0.50 \mathrm{~m}$ of SLR and the with-project conditions with $0.50 \mathrm{~m}$ of SLR. Similar patterns of erosion and deposition can be seen along the 5-m contour offshore of Pelican Island and the Fort Morgan Peninsula. Again, there are minor changes in bed levels for the with-project conditions ranging from -0.20 to $0.32 \mathrm{~m}$ near Pelican Island and -0.38 to $0.34 \mathrm{~m}$ offshore of the Fort Morgan Peninsula within the $5-\mathrm{m}$ contour (fig. 6C).

The volume of sediment eroded and deposited in the entrance channel at the end of the 2010 simulations was calculated by dividing the entrance channel into 15 sections of equal length. The volumes in each section and across the entrance channel are summarized in table 3; the percent change in each section is illustrated in figure 7 . The change in volume across the channel for the existing and with-project scenarios is 45,860 and $43,670 \mathrm{~m}^{3}$ respectively, indicating that the channel is shoaling (sand is being deposited in the channel) for both scenarios. The deeper channel (with-project condition) reduced the overall shoaling volume 

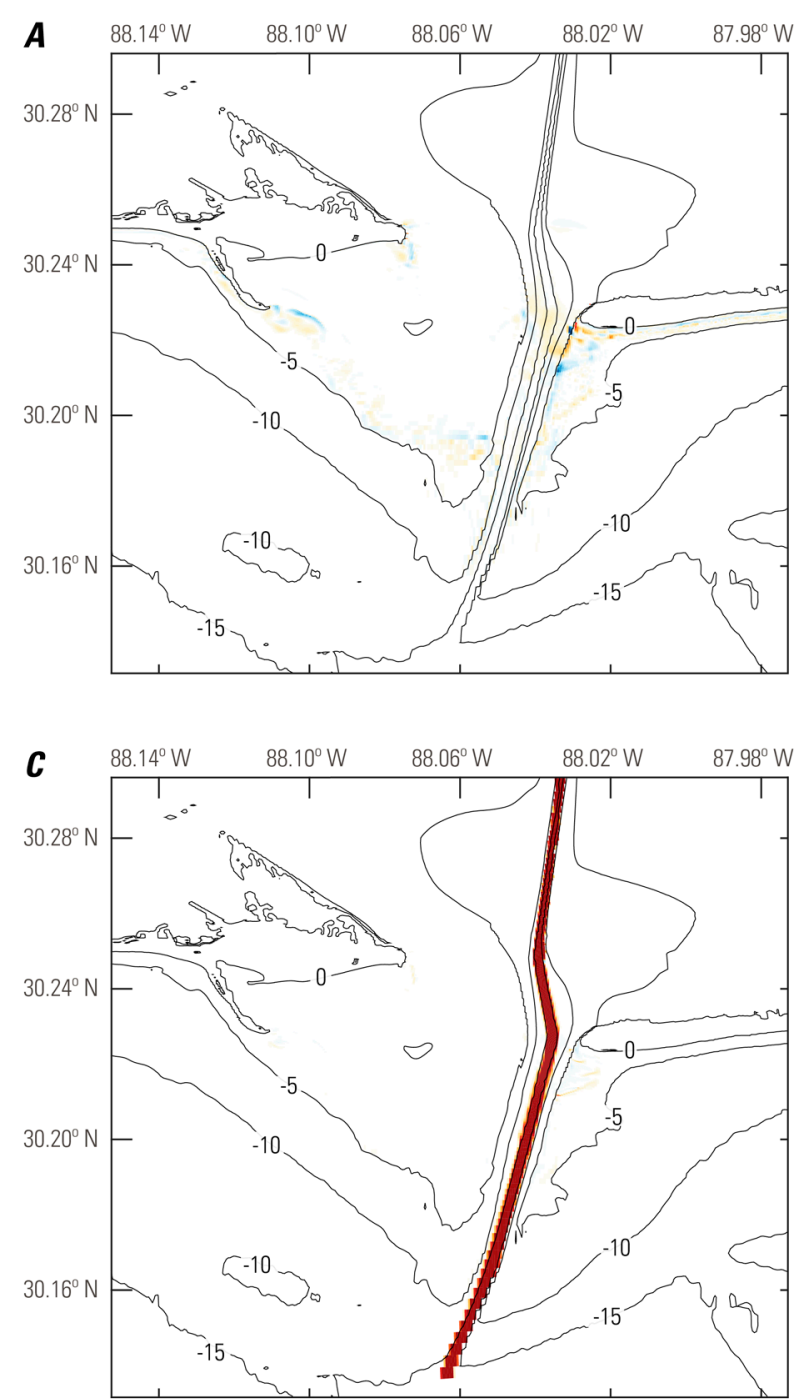

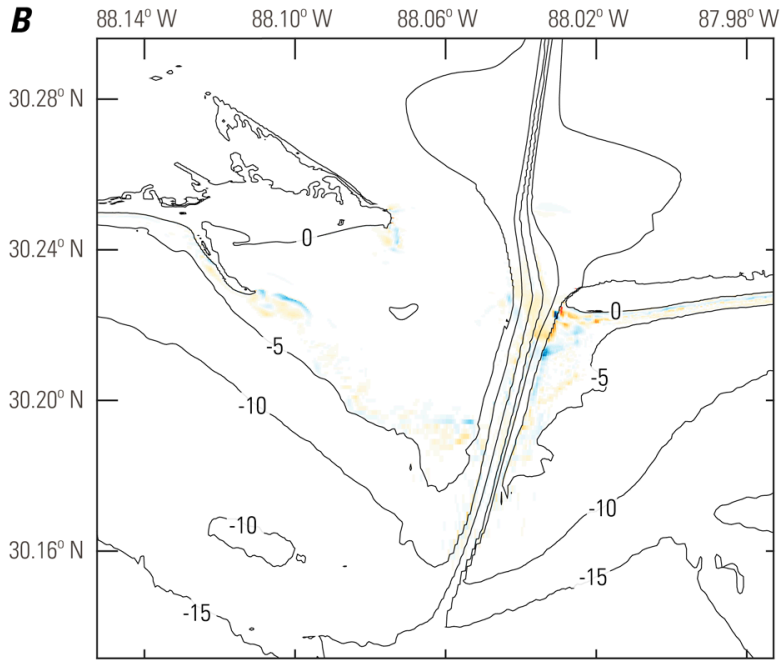

EXPLANATION

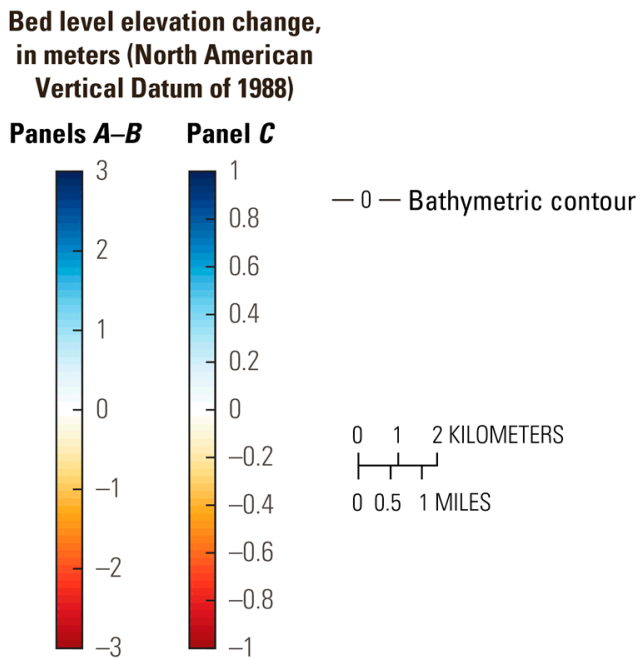

Figure 5. Changes in bed level for the 2010 simulations, Mobile Harbor, Alabama. A, existing conditions. $B$, with-project conditions. $C$, difference in final bed level between existing and with-project conditions. For $A$ and $B$, differences greater than 0 indicate deposition, differences less than 0 indicate erosion. For $C$, differences greater than 0 indicate the with-project bed level is shallower, and differences less than 0 indicate the with-project bed level is deeper.

by $2,190 \mathrm{~m}^{3}$ (4.77 percent). Under $0.50 \mathrm{~m}$ of SLR, there is less shoaling with channel volumes of 20,662 and $18,991 \mathrm{~m}^{3}$ for the existing and with-project conditions, respectively. Similarly, the with-project condition reduces the channel shoaling volume by $1,671 \mathrm{~m}^{3}$ (8.09 percent) from the existing condition. Changes in shoaling volume are negative at most sections of the entrance channel, meaning that less sand is deposited for the with-project condition, as shown in figure 7. However, a few sections in the middle of the entrance channel (6 through 9) and sections 13 and 15 have positive changes, indicating that more sand is deposited in these sections with the deeper (with-project) channel. 

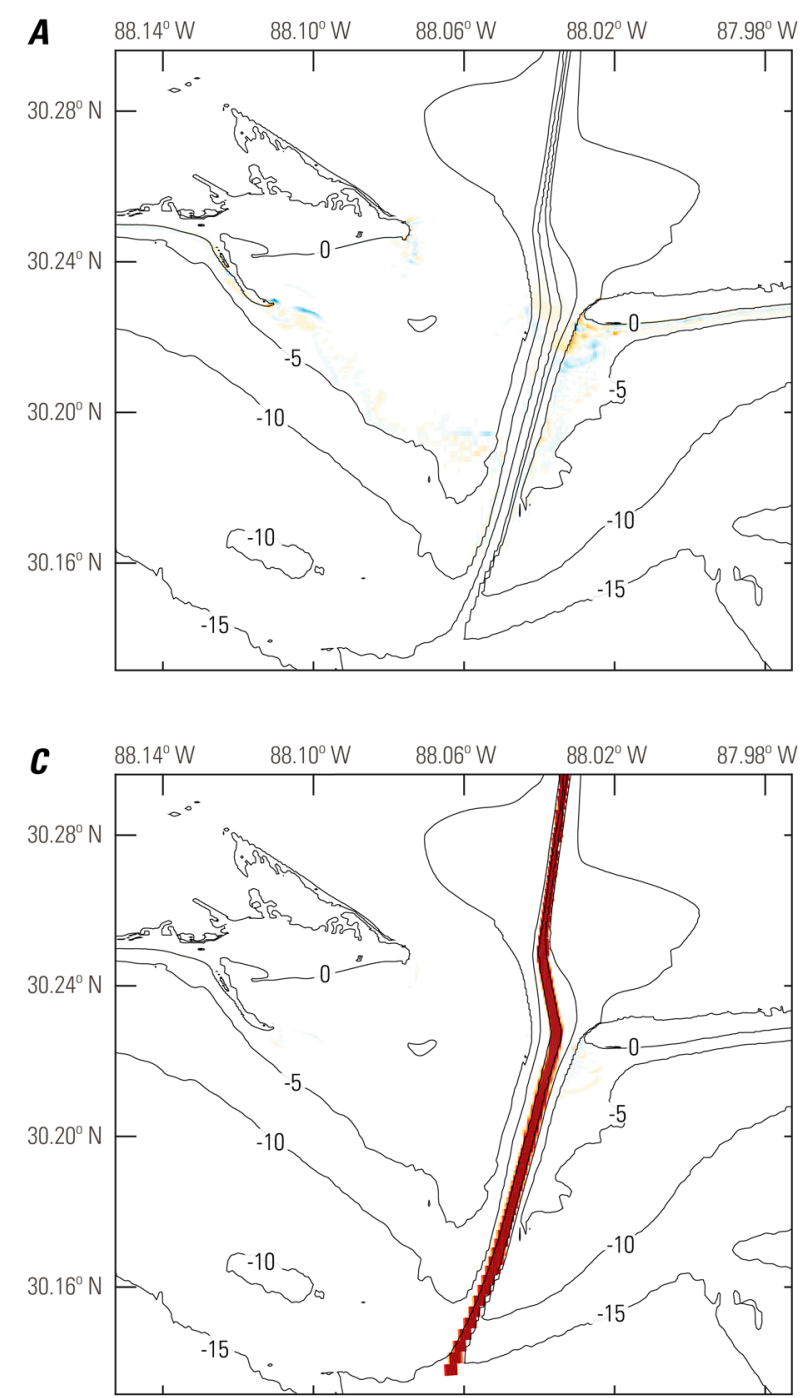

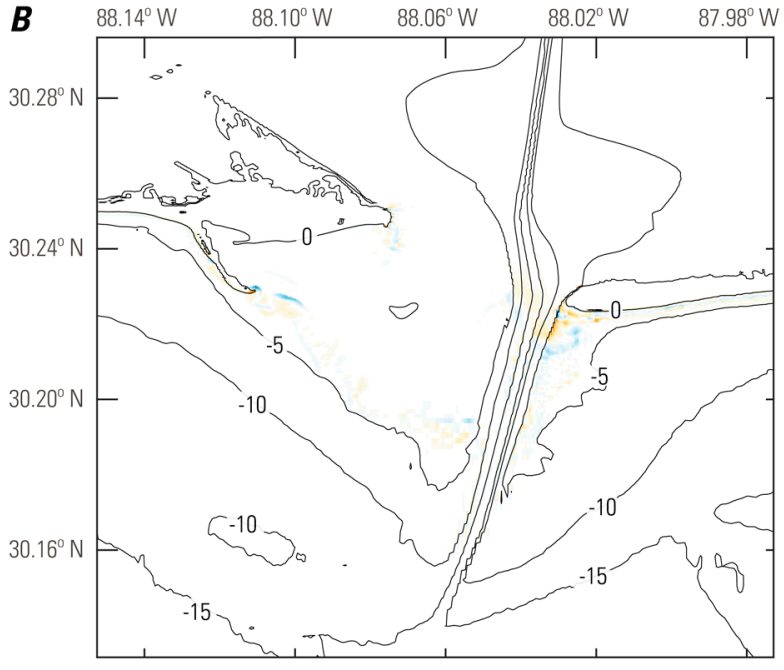

EXPLANATION

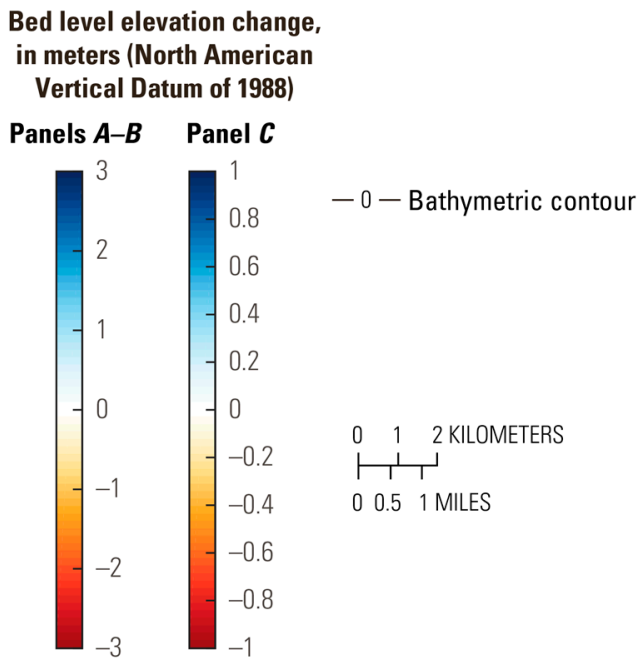

Figure 6. Changes in bed level for the 2010 simulations, Mobile Harbor, Alabama. $A$, existing conditions accounting for 0.5 meter of sea level rise. $B$, with-project conditions accounting for 0.5 meter of sea level rise. $C$, difference in final bed level between existing conditions accounting for 0.5 meter of sea level rise and with-project conditions accounting for 0.5 meter of sea level rise. For $A$ and $B$, differences greater than 0 indicate deposition, differences less than 0 indicate erosion. For $C$, differences greater than 0 indicate the bed level for the with-project condition with 0.5 meter of sea level rise is shallower than the bed level for the existing condition with 0.5 meter of sea level rise, and differences less than 0 indicate the bed level for the with-project condition with 0.5 meter of sea level rise is deeper than the bed level for the existing condition with 0.5 meter of sea level rise.

\section{0-Year Climatology}

The change in bed level at the end of the 10-year simulation (that is, the difference between the final bed level at the end of year 10 and the initial bed level at the start of the simulation) for the existing and with-project conditions is shown in figures 8A and 8B. Similar to the 2010 simulations, there is erosion and deposition in both simulations along the 5-m contour extending out from Pelican Island, as well as from the Fort Morgan Peninsula. The difference 
Table 3. Volume of sediment eroded or deposited in the entrance channel at the end of the 2010 simulations, Mobile Harbor, Alabama.

[Positive numbers indicate sand was deposited in the channel (shoaling); negative numbers indicate sand was eroded from the channel]

\begin{tabular}{ccccc}
\hline \multirow{2}{*}{$\begin{array}{c}\text { Section } \\
\text { (figs. 7, 10) }\end{array}$} & \multicolumn{4}{c}{ Sediment volume change, in cubic meters } \\
\cline { 2 - 5 } & $\begin{array}{c}\text { Existing } \\
\text { conditions }\end{array}$ & $\begin{array}{c}\text { With-project } \\
\text { conditions }\end{array}$ & $\begin{array}{c}\text { Existing conditions with } \\
\text { 0.50 }\end{array}$ & $\begin{array}{c}\text { With-project conditions with } \\
\text { o.50 level rise }\end{array}$ \\
\hline 1 & -171 & -190 & -85 & -115 \\
2 & $-1,144$ & $-1,370$ & -563 & -642 \\
3 & $-13,012$ & $-15,434$ & $-6,668$ & $-7,878$ \\
4 & $-12,306$ & $-12,704$ & $-6,458$ & $-6,608$ \\
5 & $-21,733$ & $-22,506$ & $-10,157$ & $-10,621$ \\
6 & $-21,858$ & $-20,215$ & $-12,144$ & $-11,446$ \\
7 & 15,200 & 18,455 & 5,488 & 7,621 \\
8 & 2,433 & 3,746 & $-1,569$ & -668 \\
9 & $-3,903$ & $-1,735$ & $-6,546$ & $-5,283$ \\
10 & 3,869 & 3,215 & $-1,891$ & $-2,117$ \\
11 & 44,910 & 41,969 & 20,786 & 19,041 \\
12 & 53,606 & 47,403 & 34,337 & 30,728 \\
13 & $-4,859$ & $-1,833$ & 2,754 & 3,624 \\
14 & 3,555 & 3,358 & 2,527 & 2,398 \\
15 & 1,273 & 1,511 & 850 & 955 \\
All sections & 45,860 & 43,670 & 20,662 & 18,991 \\
\hline
\end{tabular}

in the final bed levels between the existing and with-project conditions is shown in figure $8 C$. Results indicate that, with the proposed channel deepening, there are some changes in bed levels along the 5-m contour offshore of Pelican Island, ranging from -2.62 to $2.03 \mathrm{~m}$. Offshore of the Fort Morgan Peninsula, there are larger changes in bed levels ranging from -3.17 to $3.94 \mathrm{~m}$. The change in bed level at the end of the 10-year simulation for the existing and with-project conditions with $0.50 \mathrm{~m}$ of SLR is illustrated in figures 9A and 9B. There are similar patterns of erosion and deposition along the 5-m contour and near the Fort Morgan Peninsula for both simulations. With the proposed channel modifications under $0.50 \mathrm{~m}$ of SLR, changes in bed levels were smaller than for the 10-year simulations without SLR and range from -0.86 to $1.07 \mathrm{~m}$ offshore of Pelican Island and -1.92 to $1.47 \mathrm{~m}$ offshore of the Fort Morgan Peninsula (fig. 9C).

The volume of sediment in the entrance channel at the end of the year 10 was calculated at each of the 15 sections and across all sections of the channel (table 4); the percent change in each section is illustrated in figure 10. At the end of 10 years, the changes in volume across the entire channel for the existing and with-project scenarios are 40,035 and 37,816 $\mathrm{m}^{3}$, respectively, indicating that the channel is shoaling (sand was deposited in the channel). The with-project condition reduced the overall channel shoaling volume by $2,219 \mathrm{~m}^{3}$ (5.54 percent). The change in volume across the entire channel for the existing and with-project scenarios under $0.50 \mathrm{~m}$ of SLR is 17,849 and $15,175 \mathrm{~m}^{3}$, respectively. The with-project condition reduced the overall channel shoaling volume by $2,674 \mathrm{~m}^{3}$ (14.98 percent). Like the 2010 simulations, the negative changes shown in figure 10 illustrate that less sand is being deposited at most sections of the entrance 


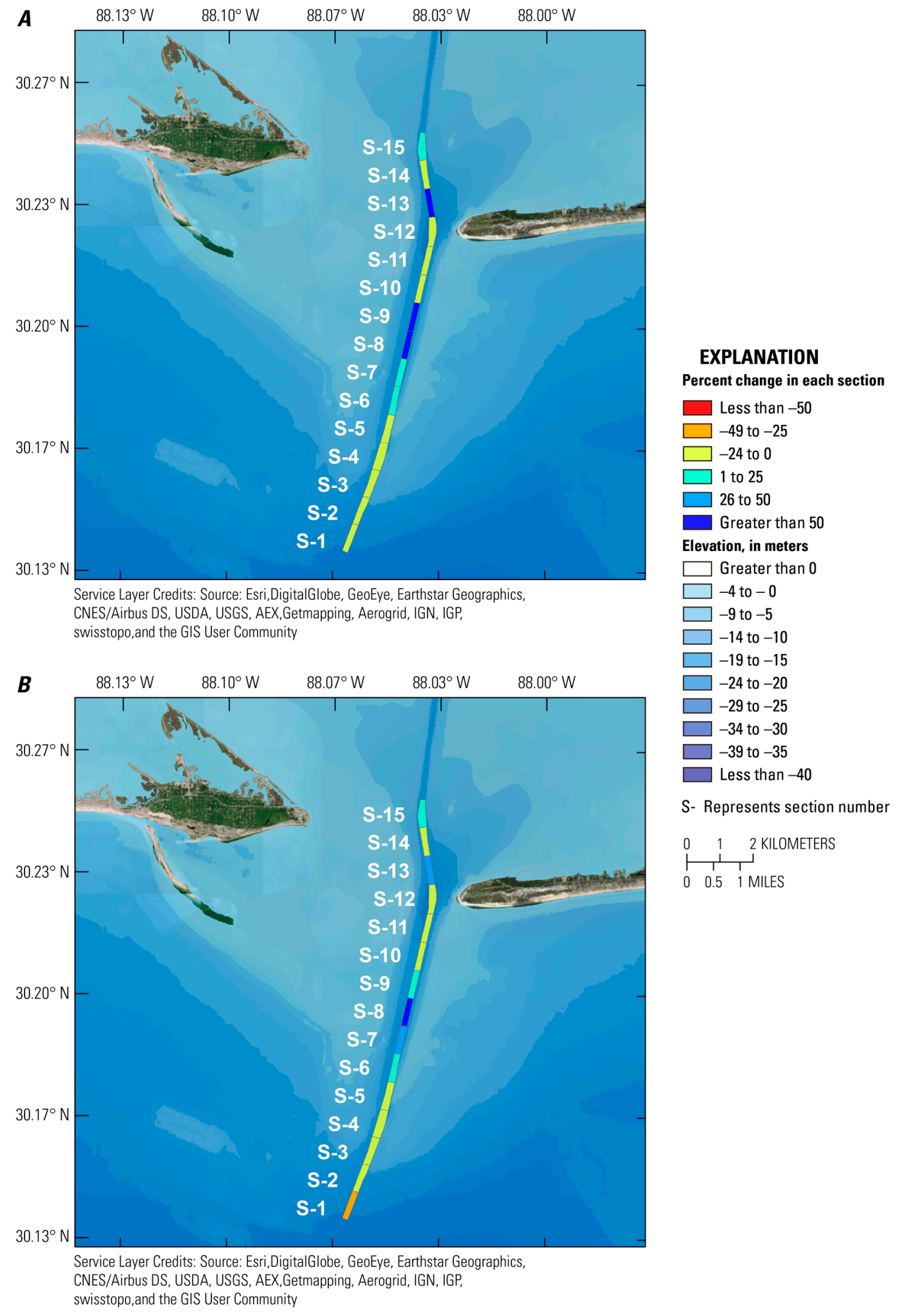

Figure 7. Percent change in the volume of sediment eroded or deposited in the entrance channel, Mobile Harbor, Alabama. A, between 2010 existing and 2010 with-project conditions. B, between 2010 existing with 0.50 meter of sea level rise and 2010 with-project with 0.50 meter of sea level rise. 

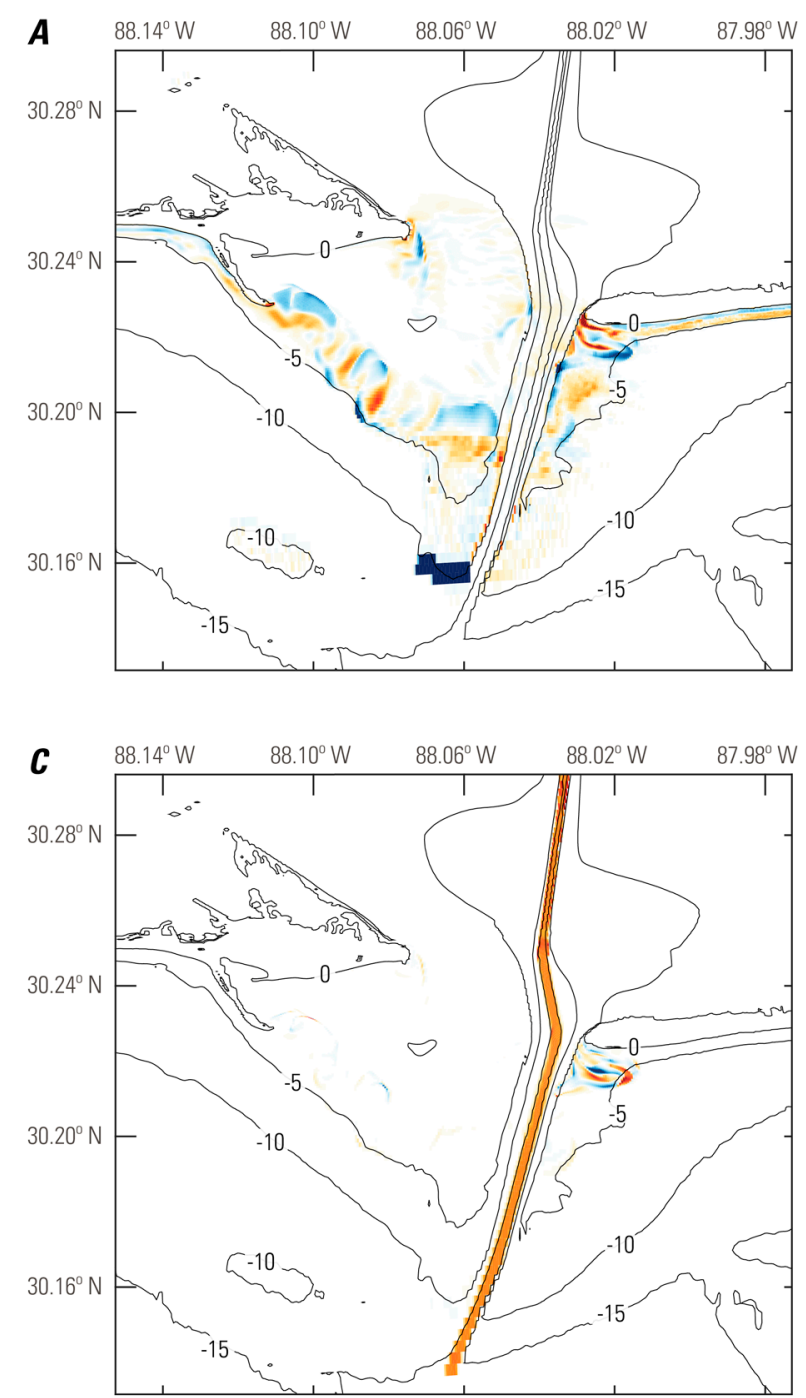

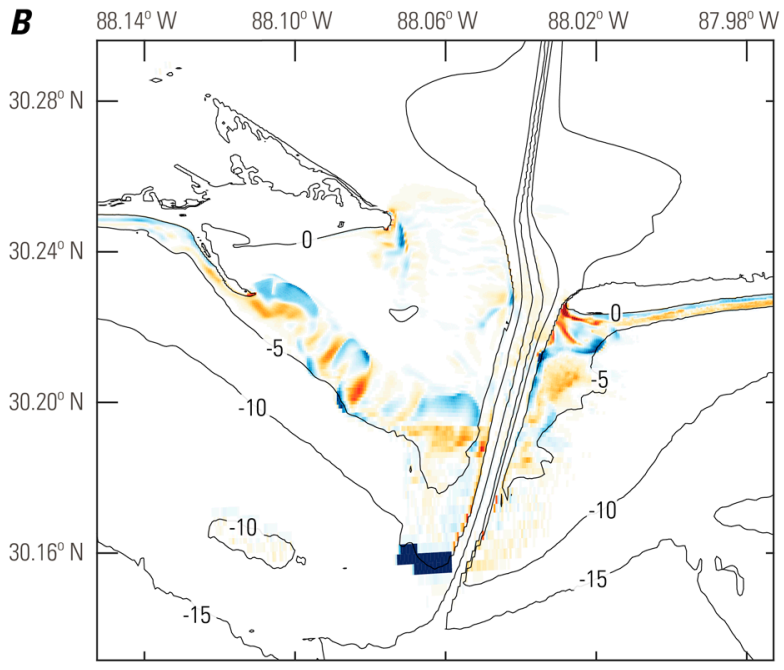

EXPLANATION

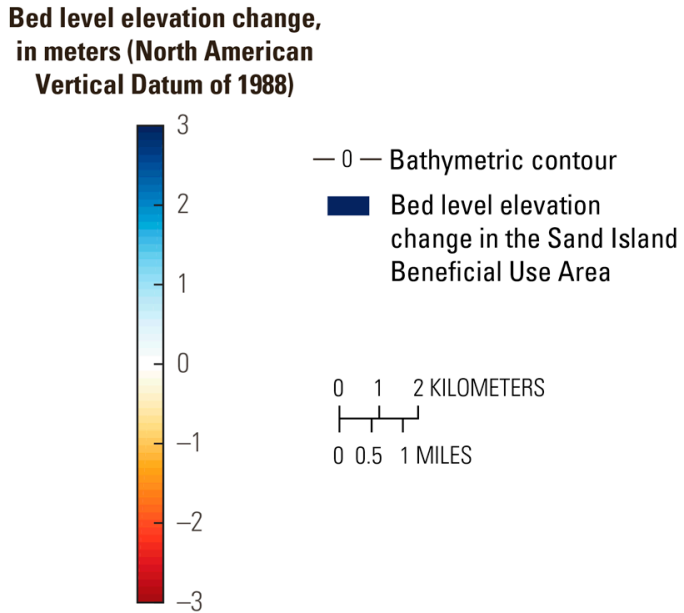

Figure 8. Changes in bed level for the 10-year simulations, Mobile Harbor, Alabama. $A$, existing conditions. $B$, with-project conditions. $C$, difference in final bed level between existing and with-project conditions. For $A$ and $B$, differences greater than 0 indicate deposition, differences less than 0 indicate erosion. For $C$, differences greater than 0 indicate the with-project bed level is shallower, and differences less than 0 indicate the with-project bed level is deeper.

channel, especially at the southern end. Again, a few sections in the middle of the entrance channel (6 through 9) and sections 13 and 15 have positive changes, indicating that more sand is deposited in these sections with the deeper (with-project) channel.

The shoaling volume across the entire entrance channel also was calculated at the end of each year in the 10-year simulation (table 5). Although elevations in the channel were reset to the initial depth at the beginning of each year, the shoaling volume at the end of each year was not equal for all simulations; the percent change in the volume varied from a 1.47-percent decrease to a 9.99-percent increase from the previous year. These fluctuations indicate that as sand shifts in offshore areas (especially near the Fort Morgan Peninsula), the resulting sediment transport into the entrance channel changes. 

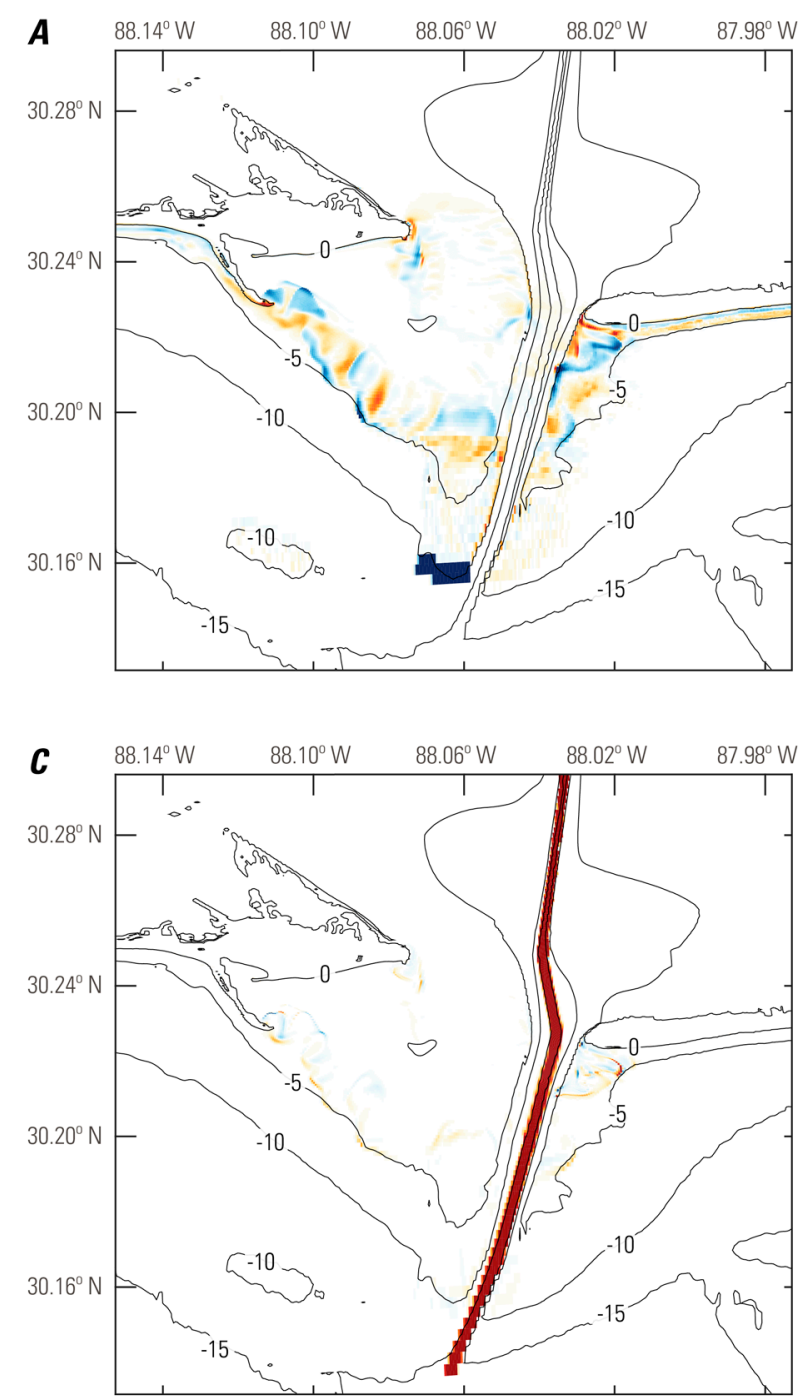

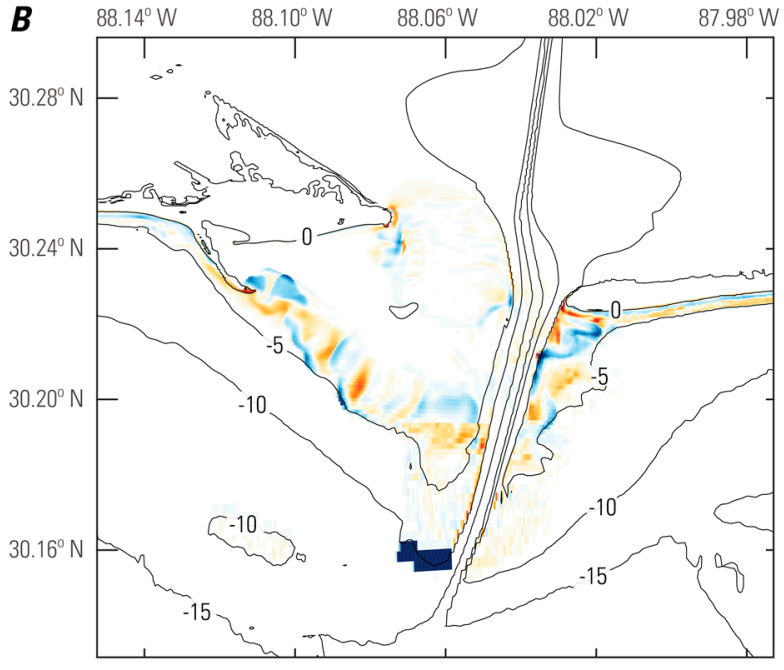

EXPLANATION

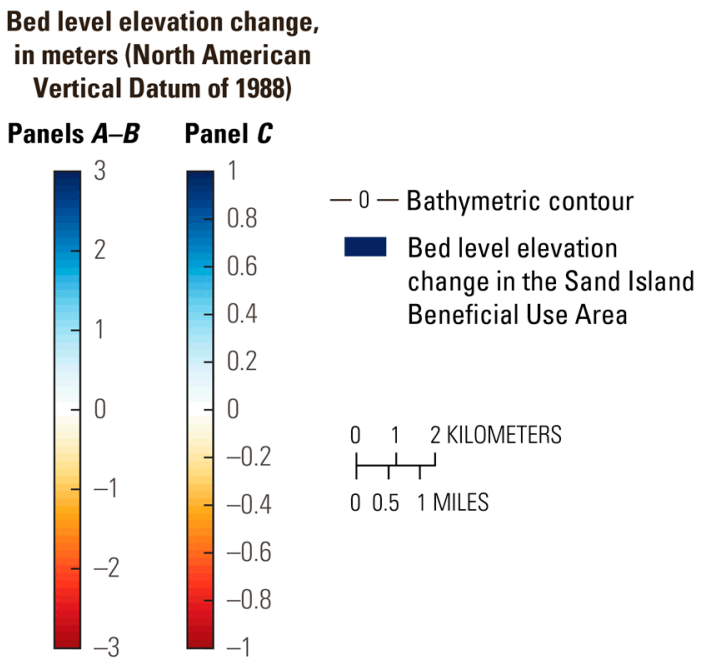

Figure 9. Changes in bed level for the 10-year simulations, Mobile Harbor, Alabama. $A$, existing conditions accounting for 0.5 meter of sea level rise. $B$, with-project conditions accounting for 0.5 meter of sea level rise. $C$, difference in final bed level between existing conditions accounting for 0.5 meter of sea level rise and with-project conditions accounting for 0.5 meter of sea level rise. For $A$ and $B$, differences greater than 0 indicate deposition, differences less than 0 indicate erosion. For $C$, differences greater than 0 indicate the bed level for the with-project condition with 0.5 meter of sea level rise is shallower than the existing condition with 0.5 meter of sea level rise, and differences less than 0 indicate the bed level for the with-project condition with 0.5 meter of sea level rise is deeper than the existing condition with 0.5 meter of sea level rise.

\section{Discussion}

The results and patterns from the existing and future with-project conditions indicated some changes in the overall dynamics of the system, especially for the 10-year simulations. There were minimal differences in morphologic change in the nearshore areas of Dauphin Island and Pelican Island because of the channel modifications (figs. 8, 9). This suggests that sediment delivery away from the ebb tidal shoal to these areas is similar under these two scenarios and that 
Table 4. Volume of sediment eroded or deposited in the entrance channel for the 10-year climatology simulations, Mobile Harbor, Alabama.

[Positive numbers indicate sand was deposited in the channel (shoaling); negative numbers indicate sand was eroded from the channel]

\begin{tabular}{ccccc}
\hline \multirow{2}{*}{$\begin{array}{c}\text { Section } \\
\text { (figs. 7, 10) }\end{array}$} & Existing conditions & $\begin{array}{c}\text { With-project } \\
\text { conditions }\end{array}$ & $\begin{array}{c}\text { Existing conditions } \\
\text { with 0.50 meter of } \\
\text { sea level rise }\end{array}$ & $\begin{array}{c}\text { With-project conditions } \\
\text { with 0.50 meter of } \\
\text { sea level rise }\end{array}$ \\
\cline { 2 - 5 } & $-1,328$ & $-1,581$ & -596 & -742 \\
2 & -534 & $-1,108$ & -63 & -230 \\
3 & $-15,532$ & $-18,680$ & $-9,042$ & $-10,819$ \\
4 & $-11,984$ & $-12,367$ & $-5,618$ & $-5,687$ \\
5 & $-24,782$ & $-26,482$ & $-10,693$ & $-11,355$ \\
6 & $-29,023$ & $-28,022$ & $-14,088$ & $-13,393$ \\
7 & 10,243 & 13,260 & 5,626 & 7,250 \\
8 & $-2,156$ & 1,450 & $-6,203$ & $-4,547$ \\
9 & $-11,460$ & $-8,587$ & $-16,910$ & $-15,473$ \\
10 & 24,661 & 21,423 & 21,054 & 18,829 \\
11 & 54,818 & 54,185 & 23,400 & 22,004 \\
12 & 52,207 & 44,659 & 24,076 & 21,709 \\
13 & 1,052 & 4,897 & 3,727 & 4,458 \\
14 & 4,562 & 4,446 & 2,402 & 2,297 \\
15 & 1,619 & 1,969 & 777 & 876 \\
All sections & 52,364 & 49,462 & 17,849 & 15,175 \\
\hline
\end{tabular}

shoreline positions are unlikely to be affected because of the modified channel. Although comparison of the two simulations shows some spatial shifting of sand offshore of the Fort Morgan Peninsula, the patterns of erosion and deposition in the two simulations are quite similar. Based on these results, it also seems unlikely that these changes would alter sediment delivery to the peninsula, and only minor effects to the terminal end of the peninsula closest to the channel could occur.

A limitation in the modeling framework is the exclusion of peak wave and storm surge characteristics associated with tropical storms. Although larger wave heights from storms are included in the full time series of the waves used to define the climatology, the nine bins were defined using mean characteristics of all waves within each bin. Therefore, the model was not forced with wave heights larger than $2.26 \mathrm{~m}$, which is smaller than peak wave heights observed during tropical storms in the Gulf of Mexico (for example, see Bilskie and others, 2016). Additionally, the simulation of each bin contains a tidal time series but does not include storm surge, which is associated with individual storms rather than the wave conditions represented by each bin. River inflow from the Mobile and Tensaw Rivers (fig. 1) also was not considered for this study because it was assumed that riverine effects on hydrodynamics and marine sediment transport would be minor around the ebb tidal shoal and Dauphin Island.

To simulate morphological change over decadal time scales, two-dimensional depth averaged velocities were used in the Delft3D simulations. This neglects the effects of vertically varying velocity profiles and boundary layer processes on morphological change. Studies have 


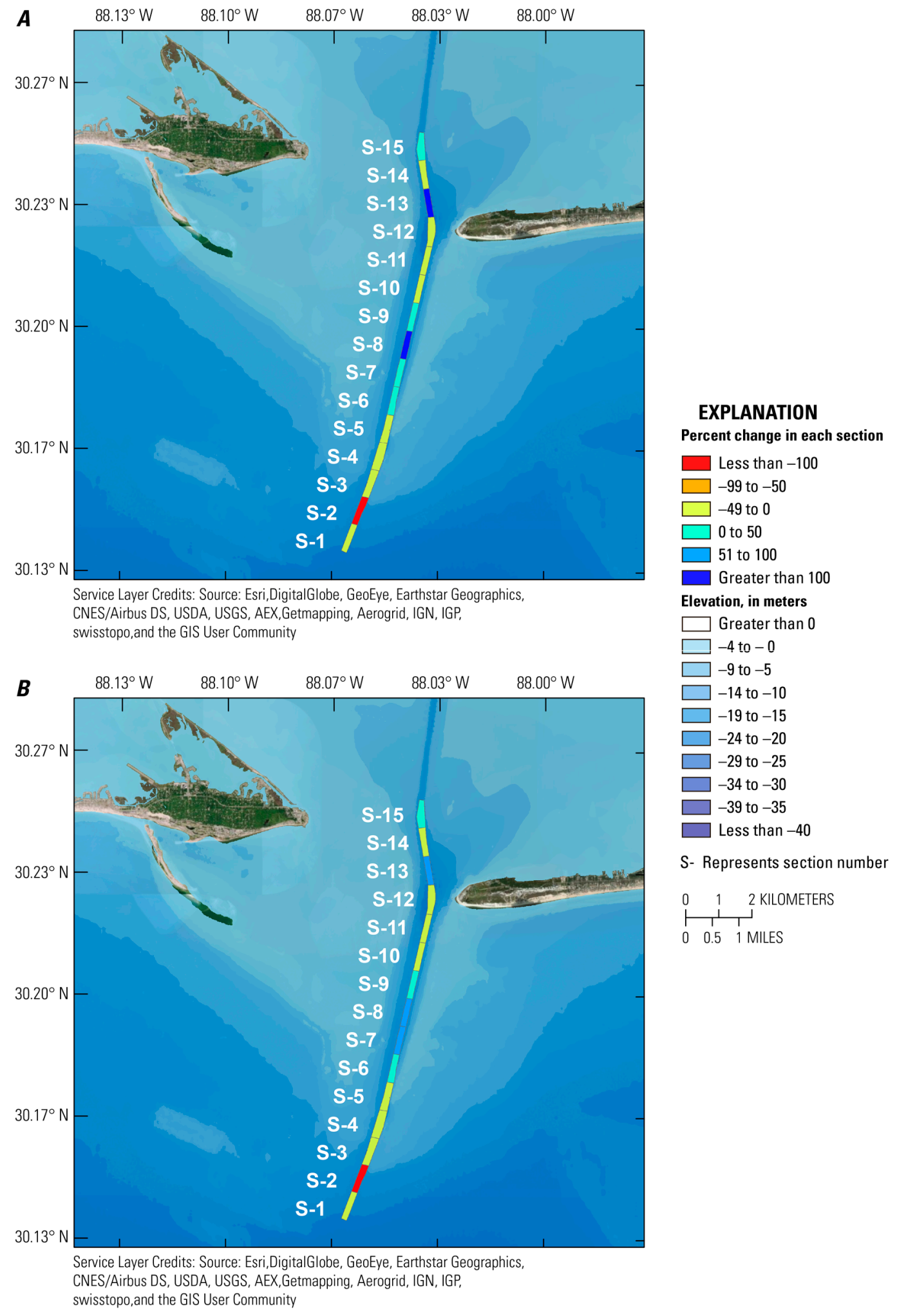

Figure 10. Percent change in the volume of sediment eroded or deposited in the entrance channel, Mobile Harbor, Alabama. A, between the 10-year existing and 10-year with-project conditions. B, between the 10-year existing condition with 0.50 meter of sea level rise and 10 -year with-project condition with 0.50 meter of sea level rise. 
Table 5. Shoaling volume in the entrance channel at the end of each year for the 10-year simulations, Mobile Harbor, Alabama.

\begin{tabular}{|c|c|c|c|c|}
\hline \multirow[b]{2}{*}{ Period } & \multicolumn{4}{|c|}{ Shoaling volume, in cubic meters (percent change in volume from the previous year) } \\
\hline & Existing conditions & $\begin{array}{l}\text { With-project } \\
\text { conditions }\end{array}$ & $\begin{array}{l}\text { Existing conditions } \\
\text { with } 0.50 \text { meter of } \\
\text { sea level rise }\end{array}$ & $\begin{array}{l}\text { With-project conditions } \\
\text { with } 0.50 \text { meter of } \\
\text { sea level rise }\end{array}$ \\
\hline After year 1 & 38,442 & 37,482 & 15,459 & 12,808 \\
\hline After year 2 & $42,284(9.99)$ & $38,474(2.65)$ & $15,726(1.73)$ & $13,283(3.71)$ \\
\hline After year 3 & $41,705(-1.37)$ & $40,078(4.17)$ & $15,633(-0.59)$ & $13,268(-0.11)$ \\
\hline After year 4 & $41,583(-0.29)$ & $39,681(-0.99)$ & $15,879(1.57)$ & $13,509(1.82)$ \\
\hline After year 5 & $41,520(-0.15)$ & $39,677(-0.01)$ & $16,322(2.79)$ & $13,836(2.42)$ \\
\hline After year 6 & $41,470(-0.12)$ & $39,404(-0.69)$ & $16,687(2.24)$ & $14,234(2.88)$ \\
\hline After year 7 & $41,217(-0.61)$ & $39,035(-0.94)$ & $17,041(2.12)$ & $14,545(2.19)$ \\
\hline After year 8 & $40,798(-1.02)$ & $38,473(-1.44)$ & $17,218(1.04)$ & $14,651(0.72)$ \\
\hline After year 9 & $40,305(-1.21)$ & $37,907(-1.47)$ & $17,218(0.00)$ & $14,607(-0.30)$ \\
\hline After year 10 & $40,035(-0.67)$ & $37,816(-0.24)$ & $17,849(3.66)$ & 15,175 (3.89) \\
\hline
\end{tabular}

determined that overall sediment transport patterns and morphology change can be accurately simulated using depth-averaged velocities, but the inclusion of three-dimensional processes could change the patterns or magnitudes shown here (Hu and others, 2009; Lapetina and Sheng, 2015). However, the relative difference between simulations with and without project conditions would likely be comparable.

\section{Summary and Conclusions}

A Delft3D model was developed to evaluate the potential effects of proposed navigation channel deepening and widening in Mobile Harbor, Alabama. Comparisons of model output from deterministic simulations with observed data of water levels, velocities, and bed level changes indicated that the model was able to capture hydrodynamic and sediment transport patterns in the study area with skill (coefficient of determination $\left[R^{2}\right]$ values were 0.93 and 0.66 for modeled versus observed through-channel $(U)$ velocities during ebb and flood tide, respectively, 0.79 and 0.30 for modeled versus observed cross-channel $(V)$ velocities during ebb and flood tide, respectively, 0.98 and 0.79 for ebb tide flux and flood tide flux, respectively, and 0.68 for modeled versus observed water levels). The model was then used to simulate changes in sediment transport with and without modifications to the navigational channel and accounting for 0.5 meter $(\mathrm{m})$ of sea level rise (SLR). Each scenario was simulated for 1 year with a wave climatology representative of the year 2010 as well as for 10 years with a longer-term wave climatology spanning from 1988 to 2016. Comparisons of model output for the with-project and existing conditions for the 2010 simulations indicated differences in bed levels ranging from -0.11 to $0.11 \mathrm{~m}$ offshore of Pelican Island and -0.81 to $0.22 \mathrm{~m}$ offshore of the Fort Morgan Peninsula. For the simulations with $0.5 \mathrm{~m}$ of SLR, differences in bed levels ranged from -0.20 to $0.32 \mathrm{~m}$ near Pelican Island and -0.38 to $0.34 \mathrm{~m}$ offshore of the Fort Morgan Peninsula. The with-project condition reduced shoaling in the entrance channel by 4.77 and 8.09 percent for the 2010 simulations without and with $0.5 \mathrm{~m}$ of SLR, respectively. For the 10 -year simulations, there were larger changes in bed levels with the proposed channel deepening; at the end of 10 years, the largest changes were 
offshore of the Fort Morgan Peninsula and ranged from -3.17 to $3.94 \mathrm{~m}$ for the simulation without SLR and -1.92 to $1.47 \mathrm{~m}$ for the simulation with $0.5 \mathrm{~m}$ of SLR. The with-project condition reduced the entrance channel shoaling volume by 5.54 percent for the simulation without SLR and 14.98 percent for the simulation with $0.5 \mathrm{~m}$ of SLR. Spatially, most of the entrance channel had less deposition except for the middle of the entrance channel, which had more deposition with the proposed channel modifications. Lastly, the shoaling volume at the end of each year in the 10-year simulations was not equal, indicating that offshore changes in bed levels especially around the Fort Morgan Peninsula affect the quantity of sediment that is transported into the channel. 


\section{References Cited}

Benedet, L., Dobrochinski, J.P.F., Walstra, D.J.R., Klein, A.H.F., and Ranasinghe, R., 2016, A morphological modeling study to compare different methods of wave climate schematization and evaluate strategies to reduce erosion losses from a beach nourishment project: Coastal Engineering, v. 112, p. 69-86. [Also available at https://doi.org/10.1016/j.coastaleng.2016.02.005.]

Bilskie, M.V., Hagen, S.C., Medeiros, S.C., Cox, A.T., Salisbury, M., and Coggin, D., 2016, Data and numerical analysis of astronomic tides, wind-waves, and hurricane storm surge along the northern Gulf of Mexico: Journal of Geophysical Research. Oceans, v. 121, no. 5, p. 3625-3658. [Also available at https://doi.org/10.1002/2015JC011400.]

Bleck, R., 2002, An oceanic general circulation model framed in hybrid isopycnic-cartesian coordinates: Ocean Modeling, v. 4, p. 55-88. [Also available at https://doi.org/10.1016/S14635003(01)00012-9.]

Byrnes, M.R., Rosati, J.D., Griffee, S.F., and Berlinghoff, J.L., 2012, Littoral sediment budget for the Mississippi Sound Barrier Islands: Vicksburg, Miss., U.S. Army Engineer Research and Development Center/Coastal and Hydraulics Laboratory (ERDC/CHL) TR-12-9, 171 p. [Also available at http://www.sam.usace.army.mil/Portals/46/docs/program_management/mscip/docs/ Appendix\%20B\%20-\%20Littoral\%20Sediment\%20Budget\%20Report.pdf.]

Center for Operational Oceanographic Products and Services, 2018, National Oceanic and Atmospheric Administration, Dauphin Island, AL - Station ID: 8735180 web page, accessed November 1, 2017 at https://tidesandcurrents.noaa.gov/stationhome.html?id=8735180.

Danielson, J.J., Brock, J.C., Howard, D.M., Gesch, D.B., Bonisteel-Cormier, J.M., and Travers, L.J., 2013, Topobathymetric model of Mobile Bay, Alabama: U.S. Geological Survey Data Series 769, accessed October 1, 2017, at https://pubs.usgs.gov/ds/769/.

Dee, D.P. and others, 2011, The ERA-Interim reanalysis: configuration and performance of the data assimilation system: Quarterly Journal of the Royal Meteorological Society, v. 137, no. 656, p. 553-597. [Also available at https://rmets.onlinelibrary.wiley.com/doi/abs/10.1002/qj.828.]

Deltares, 2018a, Delft3D-FLOW-Simulation of multi-dimensional hydrodynamic flows and transport phenomena, including sediments - User manual (ver. 3.15): The Netherlands, Deltares, accessed June 6, 2018, at https://content.oss.deltares.nl/delft3d/manuals/Delft3D-FLOW_User_ Manual.pdf.

Deltares, 2018b, Delft3D-WAVE — Simulation of short-crested waves with SWAN-User manual (ver. 3.05): The Netherlands, Deltares, accessed June 6, 2018, at https://content.oss.deltares.nl/ delft3d/manuals/Delft3D-WAVE_User_Manual.pdf.

DeWitt, N.T., Stalk, C.A., Flocks, J.G., Bernier, J.C., Kelso, K.W., Fredericks, J.J., and Tuten, T., 2017, Single-beam bathymetry data collected in 2015 nearshore Dauphin Island, Alabama: U.S. Geological Survey data release, accessed December 15, 2017, at https://doi.org/10.5066/ F7BZ648W.

Flocks, J.G., DeWitt, N.T., and Stalk, C.A., 2018, Analysis of seafloor change around Dauphin Island, Alabama, 1987-2015 (ver. 1.1, February 2018): U.S. Geological Survey Open-File Report 2017-1112, 19 p. [Also available at https://doi.org/10.3133/ofr20171112.] 
Hu, K., Ding, P., Wang, Z., and Yang, S., 2009, A 2D/3D hydrodynamic and sediment transport model for the Yangtze Estuary, China: Journal of Marine Systems, v. 77, nos. 1-2, p. 114-136. [Also available at https://doi.org/10.1016/j.jmarsys.2008.11.014.]

Lapetina, A., and Sheng, Y.P., 2015, Simulating complex storm surge dynamics-Three-dimensionality, vegetation effect, and onshore sediment transport: Journal of Geophysical Research. Oceans, v. 120, no. 11, p. 7363-7380. [Also available at https://doi.org/10.1002/2015JC010824.]

Lesser, G.R., 2009, An approach to medium-term coastal morphological modelling: Leiden, The Netherlands, CRC Press/Balkema, Delft University of Technology, Doctoral dissertation. [Also available at https://repository.tudelft.nl/islandora/object/uuid\%3A27a1 ffa0-580e-4eae-907b-ce6f901e652e.]

Lesser, G.R., Roelvink, J.A., van Kester, J.A.T.M., and Stelling, G.S., 2004, Development and validation of a three-dimensional morphological model: Coastal Engineering, v. 51, nos. 8-9, p. 883-915. [Also available at https://doi.org/10.1016/j.coastaleng.2004.07.014.].

National Data Buoy Center, 2018, Station 42040: National Oceanic and Atmospheric Administration web page, accessed December 1, 2017 at https://www.ndbc.noaa.gov/station_page.php?station $=42040$.

National Geophysical Data Center, National Environmental Satellite, Data, and Information Service, National Oceanic and Atmospheric Administration, and U.S. Department of Commerce, 2009, Mobile, Alabama 1/3 MHW coastal digital elevation model: National Oceanic and Atmospheric Administration, National Centers for Environmental Information web page, accessed December 1, 2017 at https://www.ngdc.noaa.gov/metaview/page?xml=NOAA/NESDIS/NGDC/ MGG/DEM/iso/xml/673.xml\&view=getDataView\&header=none)/.

National Ocean Service, 2014, Report for H12656: National Oceanic and Atmospheric Administration, National Centers for Environmental Information web page, accessed December 1, 2017 at https://www.ngdc.noaa.gov/nos/H12001-H14000/H12656.html.

Passeri, D.L., Long, J.W., Jenkins, R.L., and Thompson, D.M., 2018, Mobile Harbor navigation channel Delft3D model inputs and results: U.S. Geological Survey data release, https://doi.org/10.5066/P9SS1DJW.

Plant, N.G., Holland, K.T., and Puleo, J.A., 2002, Analysis of the scale of errors in nearshore bathymetric data: Marine Geology, v. 191, nos. 1-2, p. 71-86. [Also available at https://doi.org/10.1016/S0025-3227(02)00497-8.]

Roelvink, J.A., 2006, Coastal morphodynamic evolution techniques: Coastal Engineering, v. 53, nos. 2-3, p. 277-287. [Also available at https://doi.org/10.1016/j.coastaleng.2005.10.015.]

Tolman, H.L., 1989, The numerical model WAVEWATCH: a third generation model for the hindcasting of wind waves on tides in shelf seas: Communications on Hydraulic and Geotechnical Engineering, Delft University of Technology, Report 89-2, 72 p. [Also available at https://repository.tudelft.nl/islandora/object/uuid:5d12fc8b-6fa3-4c09-826c-d6955e1d33ab/ datastream/OBJ/download].

U.S. Geological Survey, 2016, USGS Lidar Point Cloud LA SoTerrebonne-GI 2015 15RCU7060 LAS 2016: U.S. Geological Survey, accessed October 1, 2017 at http://nationalmap.gov/viewer.html. 

